Svetlana V. Obydenkova and Joshua M. Pearce. Technical viability of mobile solar photovoltaic systems for indigenous nomadic communities in northern latitudes. Renewable Energy, 89,253-267 (2016). DOI:10.1016/j.renene.2015.12.036

\title{
Technical Viability of Mobile Solar Photovoltaic Systems for Indigenous Nomadic Communities in Northern Latitudes
}

Svetlana V. Obydenkova ${ }^{1}$ and Joshua M. Pearce $2,3, *$

1. School of Industrial Engineering and Management (ITM), Department of Energy Technology, KTH Royal Institute of Technology, Sweden

2. Department of Materials Science \& Engineering, Michigan Technological University

3. Department of Electrical \& Computer Engineering, Michigan Technological University

* corresponding author: 1400 Townsend Drive, Houghton, MI 49931-1295 pearce@mtu.edu

\begin{abstract}
The paper assesses the viability of photovoltaic (PV) to be used in northern latitudes as a part of energy supply system for remote nomadic camps of northern communities of indigenous people involved in reindeer husbandry. Two borderline locations were for the analysis: the southern area of Yakutia, Russia, 56 $41^{\prime} \mathrm{N} ; 1^{\circ} 0^{\circ} 46^{\prime} \mathrm{E}$, and the northernmost area in Norway, Finnmark, $68^{\circ} 51^{\prime} \mathrm{N} ; 4^{\circ} 43^{\prime} \mathrm{E}$. The analysis involved 16 simulation scenarios based on different energy consumption models, light sources and electric load schedules. It has been shown that under different economic conditions and given fuel prices a PV-based system in all scenarios is beneficial to serve camp needs when compared to solely fuel-based system. The results show incandescent lights, which are currently common for such settlements, should be replaced with LED lighting to enable PV system portability by reindeer sled. For areas with significant minimal solar flux days partial load scheduling is necessary for economically viable systems. The specific weight of the system (excluding support structure) measured as the system total weight to the number of camp residents ratio can be reduced by a factor of two for optimized loads to $5.8 \mathrm{~kg} /$ person for a low energy-intensive camps and $11.0 \mathrm{~kg} /$ person for a high energy intensive camps.
\end{abstract}

Keywords: solar photovoltaic; mobile solar; cold climate; isolated communities; nomadic; stand alone

\section{Introduction}

Solar photovoltaic (PV) technology has proven to be a reliable, sustainable [1] and economic source of power for isolated communities throughout the world including such diverse applications as detached residence [2,3] or whole villages [4,5], educational centers [5], water pumps [6], or even medical centers [5, 7]. Small load systems range from $1.3 \mathrm{kWh} /$ family for domestic needs to of about $23.1 \mathrm{kWh}$ for medical center, and are usually designed to run a radio, a television set, lamps, refrigerator, fans, charge laptops, phones, etc., however in these cases in energy-intensive applications over $1 \mathrm{~kW}$ PV hybrid systems represented more often by a combination of a PV and a fuel-fed generator and/or with wind turbine in order to become more reliable in terms of achieving a steady electricity output compared to PV alone [4,5,7].

The PV system properties of modular [8], stand alone [8,9] no fuel costs, very small operational cost requirements $[8,10]$ and long lifetime [8, 11] make distributed solar energy systems 
Svetlana V. Obydenkova and Joshua M. Pearce. Technical viability of mobile solar photovoltaic systems for indigenous nomadic communities in northern latitudes. Renewable Energy, 89,253-267 (2016). DOI:10.1016/j.renene.2015.12.036

appropriate technologies [12] for dispersed isolated rural communities. However, the vast majority of such systems have generally been located and studied in the south - under moderate to warm environments with relatively constant levels of solar flux (e.g. from 4.55-5.55 $\mathrm{kWh} / \mathrm{m}^{2} /$ day [2], or from 4.8 to $6.1 \mathrm{kWh} / \mathrm{m}^{2} /$ day [4]). Similar systems have been gradually being introduced into the daily life in some northern countries to power small navigational stations, radio repeaters, or lighthouses, residences, fish farms, water pumps with peak loads varying from 0.4 to $1.2 \mathrm{~kW}$ [13], and even in the Antarctic, providing power to bulbs, phones, laptops and other electric appliances in research centers during summer time [14-16]. However in higher latitudes (above $45^{\circ} \mathrm{N}$ ) such installations usually perform either on seasonal or on a hybrid basis (i.e. with a backup power source such as a generator). Nonetheless, in the far northern hemisphere the indigenous people live nomadic lifestyles on the taiga (or tundra) as part of reindeer herding societies, far from any roads, require daily electric power for their basic needs.

These nomadic indigenous societies rely on reindeer for meat, milk and hides in their daily life, as well as for transportation. Thus, herders prioritize the care and well-being of their animals, which necessitates taking herds to extremely remote winter pastures rich of lichens that feature high glucose content vital to survive severe winter season, or to summer pastures, where the diversity of grass and shrubs compensates for the shortage of protein and minerals [17]. This natural reindeer dependence on types of forage forces herders to take their livestock, along with human dwellings, twice per year to a distance of up to $200 \mathrm{~km}$, dependent on the local landscape and other conditions [18].

To provide comfort and security, herdsmen use nomadic camps, where inhabitants can rest after their hard daily work. The most common dwelling in a nomadic camp is a tent that in winter can be covered by hides and heated by firewood. A relatively low electric power demand still requires the delivery of generators and fuel into the taiga for electric lights, telecommunications equipment and other electric appliances. The delivery of fuel to remote dwellings can be challenging under extreme the natural conditions common in the taiga and the cost of diesel fuel is exorbitant [13]. In addition, the negative environmental, health and social impacts of the use of fossil fuels in the north are well known to the community members and northern governments $[19,20]$. Therefore, these communities are interested in alternative sources of electrical energy.

The severe environment of the far north makes providing renewable energy a challenge to meet nomadic electric needs. Biomass-based renewables do not provide self-sufficiency of energy supply chain in nomadic camps, and hydro power would only be available for stationary sites. Wind power could be more promising in this respect, however, even small wind turbines require specially trained staff for service [21]. Furthermore, comparatively low turbine operational and maintenance costs reported at about $0.01-0.015 \mathrm{US} \$ / \mathrm{kWh}$ do not include serving of the most expensive turbine components, such as gearbox and blades [22] whose failure due to an iceformation may become an issue under extreme northern conditions [23]. The other attributes of icing related to decrease of power delivered by the turbine $[23,24]$ and probable damage to surrounding goods due to ice take off from the blades [23], do not contribute eventually to the reliability of wind to power the nomadic camp. 
Svetlana V. Obydenkova and Joshua M. Pearce. Technical viability of mobile solar photovoltaic systems for indigenous nomadic communities in northern latitudes. Renewable Energy, 89,253-267 (2016). DOI:10.1016/j.renene.2015.12.036

Photovoltaic (PV) appears to be the most technologically competitive, but also beneficial for the unique herder lifestyle, including the traditional workmanship. To investigate this resource the paper utilizes HOMER to probe the potential feasibility of photovoltaic technology for nomadic camp. First, background is provided for reindeer herder communities, based on which two cases (one of the most southern in Russia, $56^{\circ} 41^{\prime} \mathrm{N}$, and northernmost, $68^{\circ} 51^{\prime} \mathrm{N}$, in Norway) with different scenarios in energy consumption are suggested to consider. Then, based on information obtained from herdsmen representatives, the electric needs of reindeer herders' nomadic camp are quantified and load profiles are modelled as for the current, as for the system powered by PV. Special attention is paid to environment conditions required to perform thorough analysis of the PV system behavior as in terms of its cost, as its components. The latter are selected from the real market media to be able to investigate the system economics. Sensitivity analysis utilizes different scenarios with regard to economic situation in Russia and Norway (e.g. fuel prices, interest rate), market analysis on the system components, technological behavior over the lifetime and, finally, its special features related to northern latitudes (e.g. albedo) and its maximal portability. Although this paper does not provide a detailed design of a PV-based system (e.g. its support structure), all the components, while being selected, are analyzed for their weight and dimensions suitable to be moved by reindeer sledge and able to perform under extremely cold environmental conditions.

\section{Background}

Northern groups of indigenous people involved largely in reindeer husbandry, as well as in hunting and fishing account for more than 180,000 people (Table 1) and are spread out over a vast geographic region (Figure 1). The most numerous society of indigenous people potentially involved in reindeer herding of over 120,000 is concentrated in Russia; however, there are also other people who may partially be active in reindeer husbandry, such as Komi, Tuvan, and Yakuts, rural population of which amount to 118,530 134,899 and 284,834, respectively [25].

Table 1: Population of Indigenous People Potentially Involved in Reindeer Husbandry, by country

\begin{tabular}{|c|l|c|}
\hline Country & \multicolumn{1}{|c|}{$\begin{array}{c}\text { Groups of Indigenous } \\
\text { People Occupied in } \\
\text { Reindeer Husbandry }\end{array}$} & $\begin{array}{c}\text { Number of Indigenous People, Living } \\
\text { in Country }\end{array}$ \\
\hline Russia, [25] & Nenets & 35,097 \\
\hline & Ents & 12,100 \\
\hline & Chukchi & 170 \\
\hline & Eveny & 13,901 \\
\hline & Evenki & 28,255 \\
\hline & Koryak & 5,036 \\
\hline & Khanty & 19,064 \\
\hline & Mansi & 5,241 \\
\hline & Dolgany & 6,045 \\
\hline & Yukagir & 863 \\
\hline
\end{tabular}


Svetlana V. Obydenkova and Joshua M. Pearce. Technical viability of mobile solar photovoltaic systems for indigenous nomadic communities in northern latitudes. Renewable Energy, 89,253-267 (2016). DOI:10.1016/j.renene.2015.12.036

\begin{tabular}{|c|c|c|}
\hline & Tofalar & 664 \\
\hline & Selkup & 2,876 \\
\hline & Chuvany & 606 \\
\hline & Uil'ta & 2,176 \\
\hline & Tozha & 1854 \\
\hline & Nganasan & 547 \\
\hline & Negidal & 358 \\
\hline & Soyot & 3,353 \\
\hline Norway, [26] & Sami & 2,936 \\
\hline Sweden, [26] & Sami & $\begin{array}{c}\text { About } 900 \text { reindeer herding companies } \\
\text { every of which may comprise one and } \\
\text { more reindeer owners and their } \\
\text { families }\end{array}$ \\
\hline China, [26] & Evenki & 234 \\
\hline Mongolia, [26] & Tsataan /Dukha & 200 \\
\hline $\begin{array}{l}\text { The United } \\
\text { States (Alaska), } \\
\text { [26] }\end{array}$ & Inupiaq & 21 \\
\hline Finland, [27] & $\begin{array}{l}\text { Sami and also Finns who } \\
\text { also occupied in reindeer } \\
\text { husbandry }\end{array}$ & $\begin{array}{c}5,344 \text { - total; about } 800 \text { - } 1000 \text { of } \\
\text { which are Sami }\end{array}$ \\
\hline Canada [28] & Inuvialuit / Sámi & 3668 \\
\hline
\end{tabular}

The distribution of reindeer herding across the world is quite wide. It may take place in temperate, subarctic and even arctic zones, carried out usually on uplands and highlands, and spread from northernmost parts of Mongolia and China to northernmost continental parts of Fennoscandia, Russia and Canada (Fig.1).

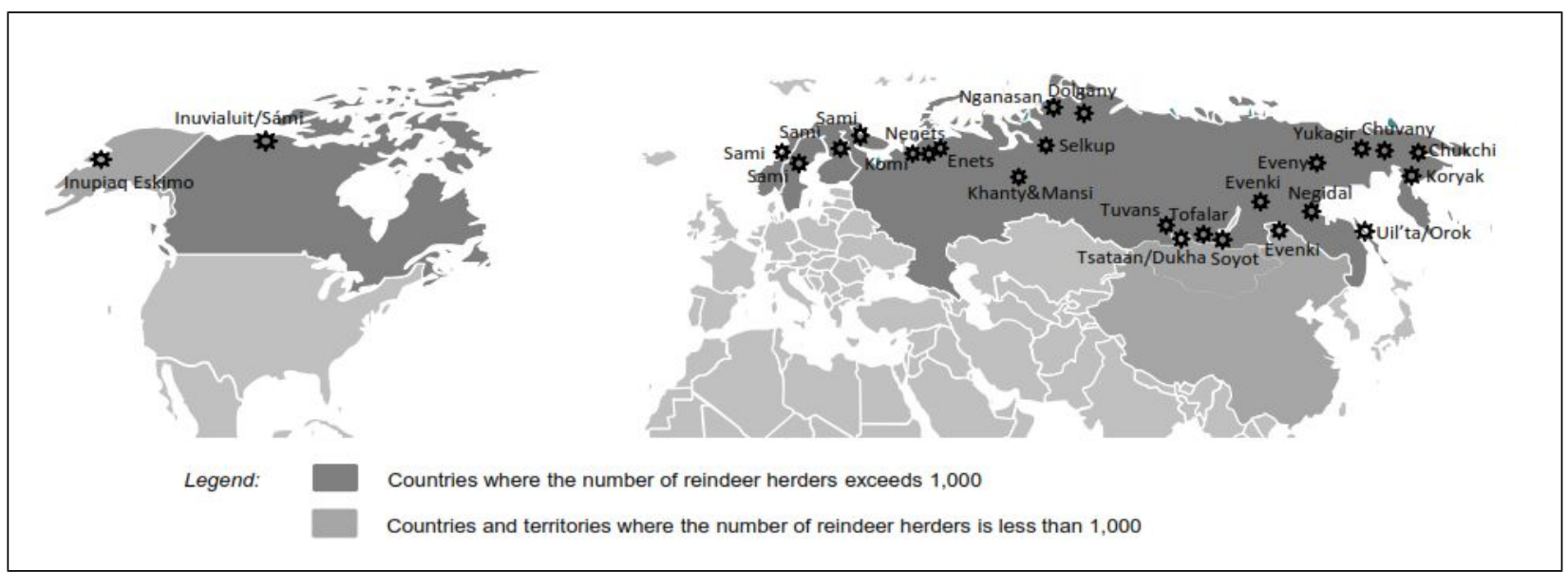

Figure 1 - Reindeer husbandry distribution map.

According to reindeer husbandry traditions, summer and winter pastures are usually divided between reindeer-herding groups, co-operatives or small crews and brigades [27, 29]; each of those may comprise several families [30, 31]. Every crew usually sets up its own nomadic camp, which can accommodate up to sixteen or more people. These camps consume a relatively low 
Svetlana V. Obydenkova and Joshua M. Pearce. Technical viability of mobile solar photovoltaic systems for indigenous nomadic communities in northern latitudes. Renewable Energy, 89,253-267 (2016). DOI:10.1016/j.renene.2015.12.036

amount of electricity, about $1.44-2.73 \mathrm{kWh} /$ day, depending on the electric appliances deployed by each crew.

Designing PV systems for reindeer herders is complicated by four primary challenges: 1) the nomadic lifestyle, which necessitates a mobile PV system able to be transported via reindeersleigh; 2) PV racking, which cannot use standard ground mounts (permafrost prevents pole mounts), ballasted racks (reindeer transport) nor roof/integrated in buildings (tents are the primary structure); 3 ) extreme temperatures $\left(-40^{\circ} \mathrm{C}\right)$ effect on battery performance and lifetime and 4) wide seasonal and daily variations in solar flux.

\section{Methods}

The modelling of the PV based system has been performed using the HOMER (Hybrid Optimization Modeling Software) software (version 2.68 beta). The methodology includes several consecutive stages outlined in Figure 2.

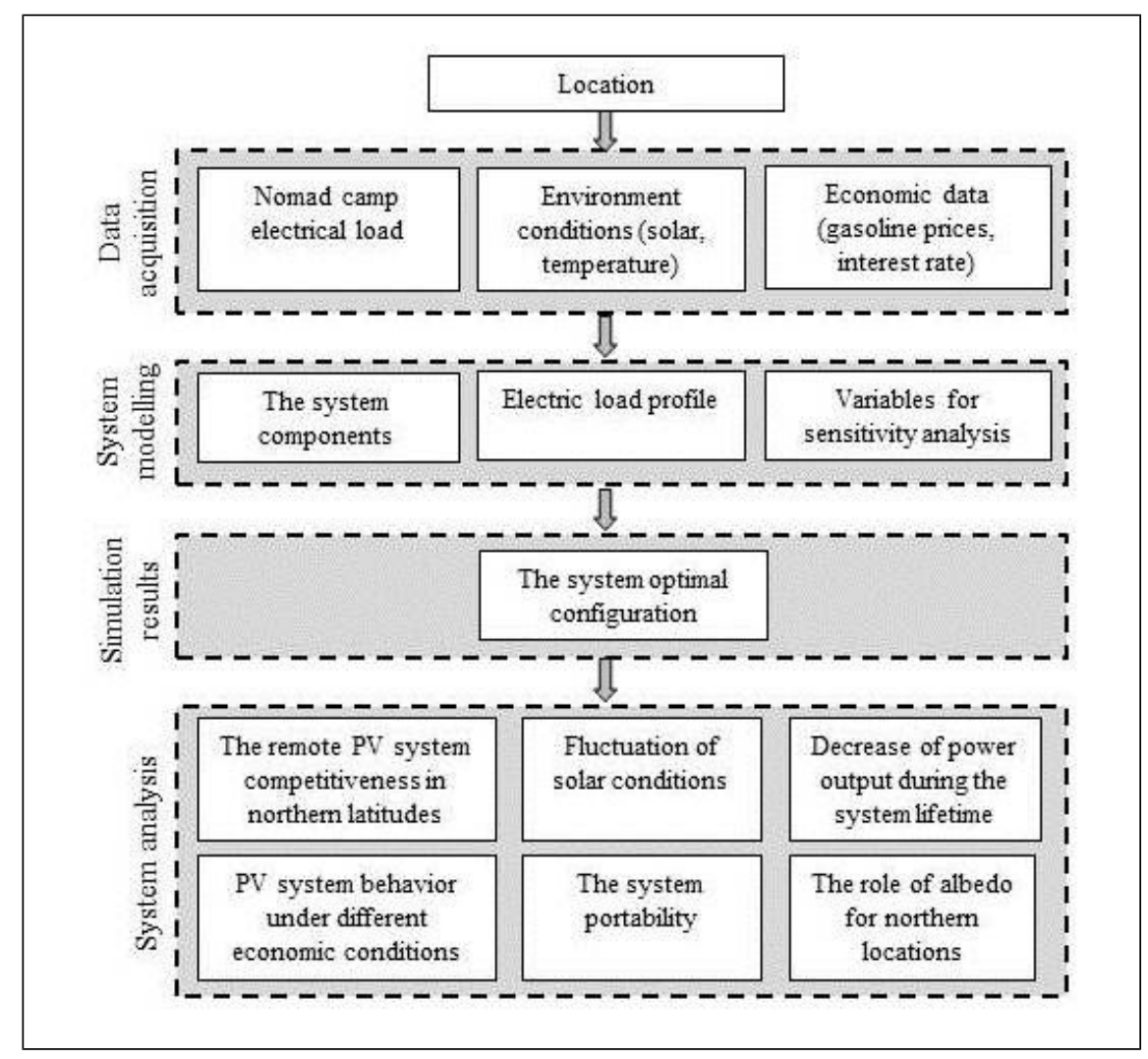

Fig. 2. The scheme of methodology

The two case study location evaluated are 1) the southern area of Yakutia, Russia $\left(56^{\circ} 41^{\prime} \mathrm{N}\right.$; $120^{\circ} 46^{\prime} \mathrm{E}$ ) - the Russian case and 2) one of the northernmost regions in Norway (Finnmark, $68^{\circ} 51^{\prime} \mathrm{N}$; $24^{\circ} 43^{\prime} \mathrm{E}$ as the winter pastures and $70^{\circ} 03^{\prime} \mathrm{N}$; $23^{\circ} 27^{\prime} \mathrm{E}$ as the summer pastures) - the 
Svetlana V. Obydenkova and Joshua M. Pearce. Technical viability of mobile solar photovoltaic systems for indigenous nomadic communities in northern latitudes. Renewable Energy, 89,253-267 (2016). DOI:10.1016/j.renene.2015.12.036

Norwegian case (Fig. 3, 4). The Norwegian case is in the Arctic Circle and the Russian case is located at higher altitudes of $1009 \mathrm{~m}$ above sea level.

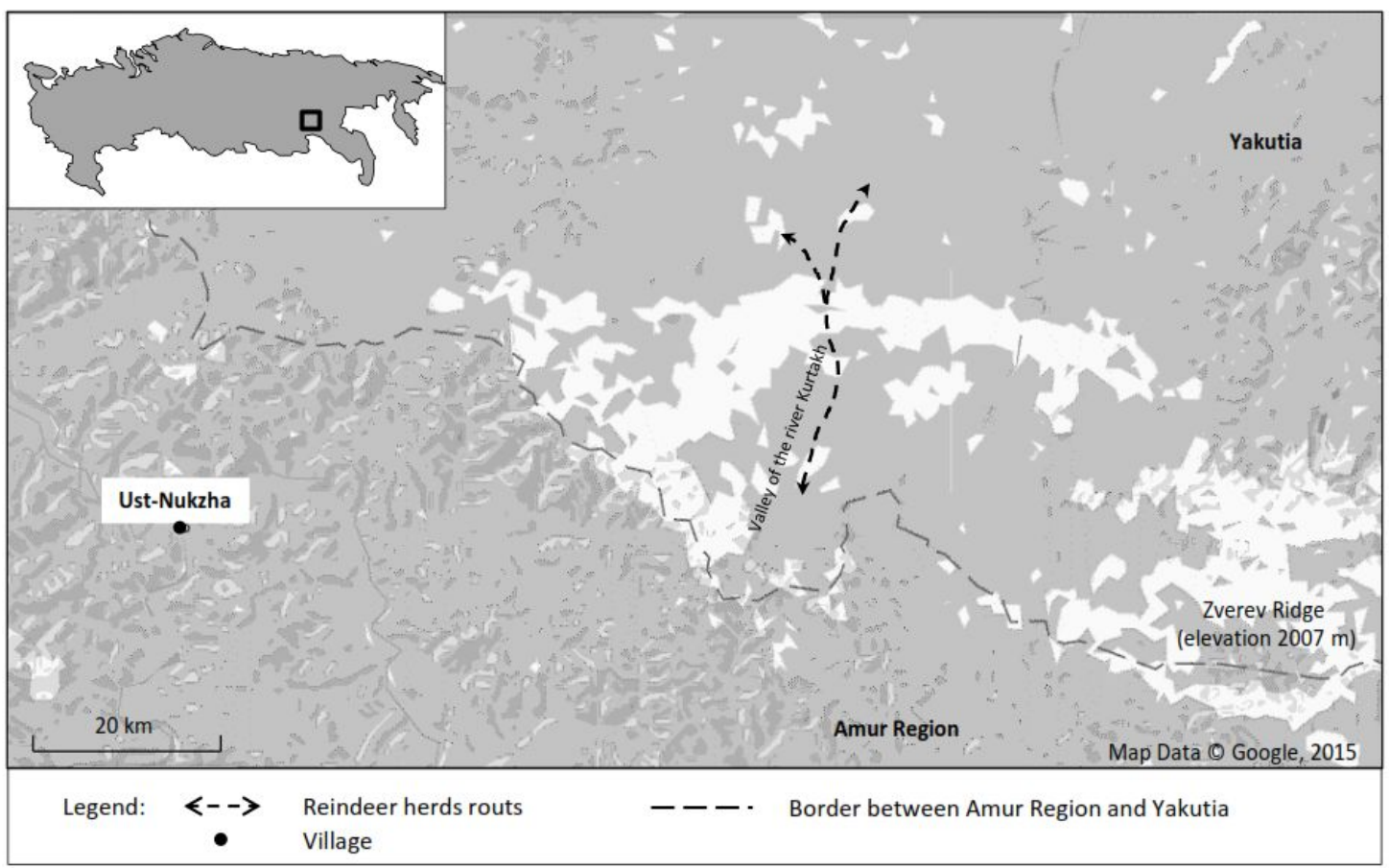

Fig. 3. Case study 1: Nomadic camp movement between winter and summer pastures. The distance to the nearest settlement, Ust-Nukzha, is of about 70 - $100 \mathrm{~km}$.

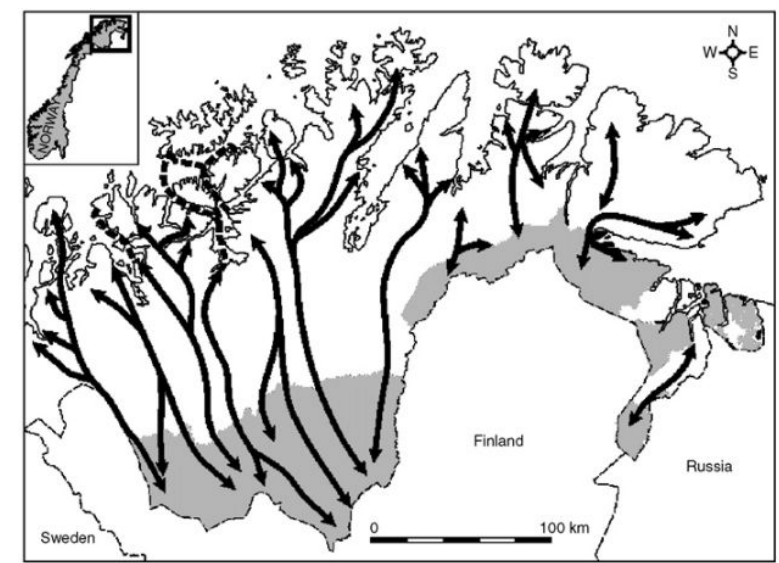

Fig. 4. Case study 2: Winter and summer locations of reindeer herders in Finnmark (Northern Norway). The map was taken from [31]. Winter pastures are marked by grey color.

Due to the ample variations of power consumed by the camps depending on the number of habitants and/or economic means, two scenarios were developed for each case study location, namely: high and low energy intensive camp (Fig. 5). As a research on the Russian herder community revealed, incandescent lamps are in a common use in camps, nonetheless, more energy-efficient light-emitting diode (LED) sources for the evening time lighting have been also 
Svetlana V. Obydenkova and Joshua M. Pearce. Technical viability of mobile solar photovoltaic systems for indigenous nomadic communities in northern latitudes. Renewable Energy, 89,253-267 (2016). DOI:10.1016/j.renene.2015.12.036

considered, thus resulting in two sub-scenarios. Additionally, two scenarios for electric load were considered, bringing a total analysis to 16 cases as summarized in Figure 5.

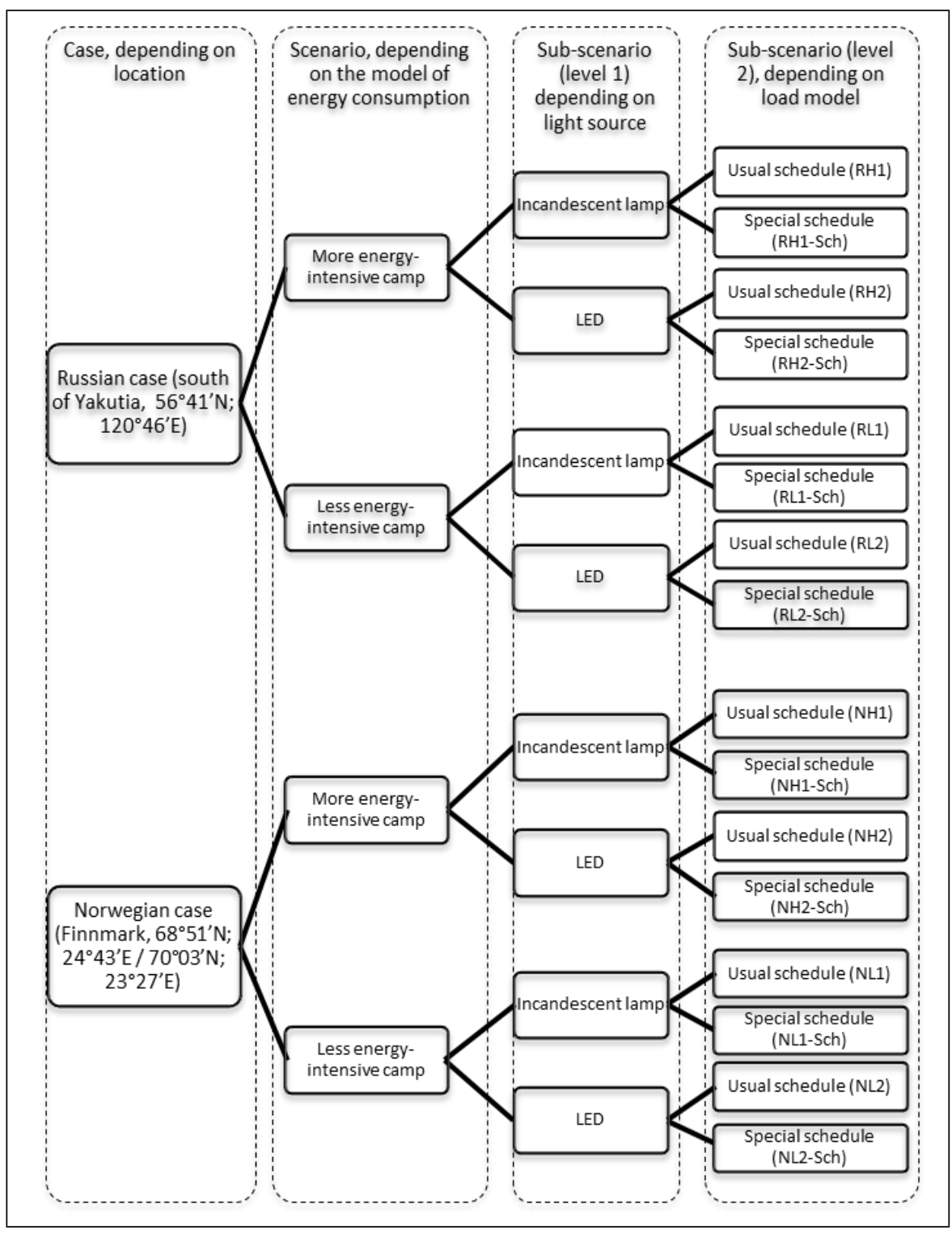

Fig.5. Scenario tree.

Announced by NREL PV system life cycle of approximately 25 [10] was reduced by 5 years that mainly is due to the system portable application.

\subsection{Data Acquisition}

\subsubsection{Nomad Camp Electrical Assessment}

Power consumption by two nomadic camps of Evenk communities was investigated when the camps were settled remotely in the taiga, in the southern part of Yakutia, the Russian Far East. The data on power demand was obtained from communities' representatives via e-mail and phone interviews. 
Svetlana V. Obydenkova and Joshua M. Pearce. Technical viability of mobile solar photovoltaic systems for indigenous nomadic communities in northern latitudes. Renewable Energy, 89,253-267 (2016). DOI:10.1016/j.renene.2015.12.036

According to the data, communities differ in the quantity of members, tents deployed in the nomadic camp and a number of appliances exploited that depend on the variety of factors such as people habits, financial means, etc. For instance, the community “Agdan”, comprising 16 people, uses eight tents, while the other community called "Nadezhda", comprising 17 people, possesses only four tents.

Electric power supplied by generators is used to provide interior lighting and charge telecommunications equipment such as satellite phones, which are gradually replacing once popular radio-transmitters, more rare mobile phones (due to the remoteness from any cell towers), and also to power laptops and video-players. This equipment is used on a daily basis, several hours per day. For the lighting, local communities usually rely on 40 or $60 \mathrm{~W}$ incandescent lamps. In addition, there are small washing machines with a nominal load of $1 \mathrm{~kg}$ of clothes [32], which are used as required, but usually at least once and twice per week in winter and summer seasons, respectively. Washing machines are used in several consecutive cycles during one day.

The information on electrical equipment, power draw, and times of use for both communities is summarized in Table 2. Data on power consumption by mobile phones and laptops was obtained from Lawrence Berkeley National Laboratory [33]. Standby power, and the rest of data was obtained from manufacturer catalogs.

Table 2 - Electric load of nomadic camps

\begin{tabular}{|c|c|c|c|c|c|c|}
\hline \multicolumn{7}{|l|}{$\begin{array}{l}\text { Community “Agdan” - } 16 \text { people, } 8 \text { tents } \\
\text { Equipment exploited on a daily basis (average) }\end{array}$} \\
\hline \multirow[t]{2}{*}{ Appliance type } & \multirow{2}{*}{$\begin{array}{l}\text { Numb } \\
\text { er in } \\
\text { use }\end{array}$} & \multirow[t]{2}{*}{$\begin{array}{l}\text { Power, } \\
\text { Watt }\end{array}$} & \multicolumn{2}{|c|}{$\begin{array}{l}\text { Winter (October- } \\
\text { April) }\end{array}$} & \multicolumn{2}{|c|}{$\begin{array}{l}\text { Summer (May- } \\
\text { September) }\end{array}$} \\
\hline & & & h/day & kWh/day & h/day & $\mathrm{kWh} / \mathrm{d}_{\mathrm{c}}$ \\
\hline Incandescent lamp of 60W & 8 & 480 & 5 & 2.4 & 2 & 0.96 \\
\hline Satellite phone (on, charging, max) & 1 & 6.9 & 2 & 0.014 & 2 & 0.014 \\
\hline Mobile phone (on, charging, $\max$ ) & 4 & 30 & 2 & 0.06 & 2 & 0.06 \\
\hline $\begin{array}{l}\text { Laptop, } 14-15 ” \text { or video player (on, } \\
\text { charging, max) }\end{array}$ & 6 & 401.4 & 2 & 0.803 & 2 & 0.803 \\
\hline \multicolumn{7}{|l|}{ Equipment exploited once or twice per week } \\
\hline \multirow[t]{2}{*}{ Appliance type } & $\begin{array}{l}\text { Numb } \\
\text { er in } \\
\text { use }\end{array}$ & $\begin{array}{c}\text { Power, } \\
\text { Watt }\end{array}$ & \multicolumn{2}{|c|}{$\begin{array}{l}\text { Winter (October- } \\
\text { April) }\end{array}$} & \multicolumn{2}{|c|}{$\begin{array}{l}\text { Summer (May- } \\
\text { September) }\end{array}$} \\
\hline & & & h/day & $\begin{array}{c}\mathrm{kWh} / \text { wee } \\
\mathrm{k}\end{array}$ & h/day & $\begin{array}{c}\mathrm{kWh} / \mathrm{w} \\
\mathrm{k}\end{array}$ \\
\hline $\begin{array}{l}\text { Washing machine with nominal loading of } \\
1 \mathrm{~kg} \text { of washing; with one washing cycle of } \\
15 \text { min }\end{array}$ & 1 & 140 & 1 & 0.14 & 2 & 0.28 \\
\hline Total: & \multicolumn{6}{|c|}{ Average load: $2.73 \mathrm{kWh} /$ day } \\
\hline
\end{tabular}


Svetlana V. Obydenkova and Joshua M. Pearce. Technical viability of mobile solar photovoltaic systems for indigenous nomadic communities in northern latitudes. Renewable Energy, 89,253-267 (2016). DOI:10.1016/j.renene.2015.12.036

\begin{tabular}{|c|c|c|c|c|c|c|}
\hline \multicolumn{7}{|l|}{ Community “Agdan" - 16 people, 8 tents } \\
\hline \multicolumn{7}{|l|}{ Equipment exploited on a daily basis (average) } \\
\hline \multirow[t]{2}{*}{ Appliance type } & \multirow{2}{*}{$\begin{array}{l}\text { Numb } \\
\text { er in } \\
\text { use }\end{array}$} & \multirow[t]{2}{*}{$\begin{array}{c}\text { Power, } \\
\text { Watt }\end{array}$} & \multicolumn{2}{|c|}{$\begin{array}{l}\text { Winter (October- } \\
\text { April) }\end{array}$} & \multicolumn{2}{|c|}{$\begin{array}{l}\text { Summer (May- } \\
\text { September) }\end{array}$} \\
\hline & & & h/day & kWh/day & h/day & $\mathrm{kWh} / \mathrm{d}_{\mathrm{c}}$ \\
\hline \multicolumn{7}{|l|}{ Community "Nadezhda" - 17 people, 4 tents } \\
\hline \multicolumn{7}{|l|}{ Equipment exploited on a daily basis (average) } \\
\hline \multirow[t]{2}{*}{ Appliance type } & \multirow[t]{2}{*}{$\begin{array}{l}\text { Numb } \\
\text { er in } \\
\text { use }\end{array}$} & \multirow[t]{2}{*}{$\begin{array}{l}\text { Power, } \\
\text { Watt }\end{array}$} & \multicolumn{2}{|c|}{$\begin{array}{l}\text { Winter (October- } \\
\text { April) }\end{array}$} & \multicolumn{2}{|c|}{$\begin{array}{l}\text { Summer (May- } \\
\text { September) }\end{array}$} \\
\hline & & & $\mathrm{h} /$ day & kWh/day & h/day & $\mathrm{kWh} / \mathrm{d}$ \\
\hline Incandescent lamp of 60W & 4 & 240 & 5 & 1.2 & 2 & 0.48 \\
\hline Satellite phone (on, charging, max) & 1 & 6.9 & 2 & 0.014 & 2 & 0.014 \\
\hline Mobile phone (on, charging, max) & 4 & 30 & 2 & 0.06 & 2 & 0.06 \\
\hline $\begin{array}{l}\text { Laptop, 14-15” or video player (on, } \\
\text { charging, max) }\end{array}$ & 3 & 200.7 & 2 & 0.401 & 2 & 0.401 \\
\hline \multicolumn{7}{|l|}{ Equipment exploited once or twice per week } \\
\hline \multirow[t]{2}{*}{ Appliance type } & \multirow[t]{2}{*}{$\begin{array}{l}\text { Numb } \\
\text { er in } \\
\text { use }\end{array}$} & $\begin{array}{c}\text { Power, } \\
\text { Watt }\end{array}$ & \multicolumn{2}{|c|}{$\begin{array}{c}\text { Winter (October- } \\
\text { April) }\end{array}$} & \multicolumn{2}{|c|}{$\begin{array}{l}\text { Summer (May- } \\
\text { September) }\end{array}$} \\
\hline & & & $\mathrm{h} /$ day & $\begin{array}{c}\mathrm{kWh} / \text { wee } \\
\mathrm{k}\end{array}$ & h/day & $\begin{array}{c}\mathrm{kWh} / \mathrm{w} \\
\mathrm{k}\end{array}$ \\
\hline $\begin{array}{l}\text { Washing machine with nominal loading of } \\
1 \mathrm{~kg} \text { of washing; with one washing cycle of } \\
15 \text { min }\end{array}$ & 1 & 140 & 1 & 0.14 & 2 & 0.28 \\
\hline Total: & \multicolumn{6}{|c|}{ Average load: $1.44 \mathrm{kWh} /$ day } \\
\hline
\end{tabular}

Generators are run all year round, from 6 p.m. till 11 p.m. in winter, and from 8 or 9 p.m. till 11 p.m. in the summer season. The most common types of generators are model DDE GG950 DC, gasoline-fired, with the rated capacity of $650 \mathrm{~W}$ [34]. Generators are run on a gasoline-oil mixture (50:1).

A survey carried out on the real fuel consumption revealed that it may vary greatly from one community to another, and also varies by seasons, that, in its turn, depends on the set of other fuel consuming equipment exploited by herders. For instance, during the 2013/2014 winter season, the Agdan community spent 4,400L of gasoline while, in the summer season, 2014, the Nadezhda community consumed only 380L of gasoline, however in both cases this amount included fuel consumed by chainsaws, snowmobiles, trucks and boats. These communities use gasoline as $-40^{\circ} \mathrm{C}$ temperatures make the use of diesel unviable. The power consumption by Sami nomadic camp was assumed to fit within the range of electric loads found in Table 2.

\subsubsection{Environmental Conditions}


Svetlana V. Obydenkova and Joshua M. Pearce. Technical viability of mobile solar photovoltaic systems for indigenous nomadic communities in northern latitudes. Renewable Energy, 89,253-267 (2016). DOI:10.1016/j.renene.2015.12.036

Data on temperature range and solar radiation were obtained from NASA Atmospheric Science Data Center [35] and for the Russian case also partly from the Russian Construction Code [36].

The average insolation incident on a horizontal surface for the case study locations amounts to 3.05 for the Russian case $\left(56^{\circ} 41^{\prime} \mathrm{N} ; 120^{\circ} 46^{\prime} \mathrm{E}\right)$, and $2.23 \mathrm{kWh} / \mathrm{m}^{2} /$ day for the Norwegian case $\left(68^{\circ} 51^{\prime} \mathrm{N}\right.$; $24^{\circ} 43^{\prime} \mathrm{E} / 7^{\circ} 03^{\prime} \mathrm{N}$; $\left.23^{\circ} 27^{\prime} \mathrm{E}\right)$, with a fairly high mean clearness index of 0.509 and 0.471 (Fig. 6), respectively, that is usual for uplands and highlands where reindeer herding usually takes place.

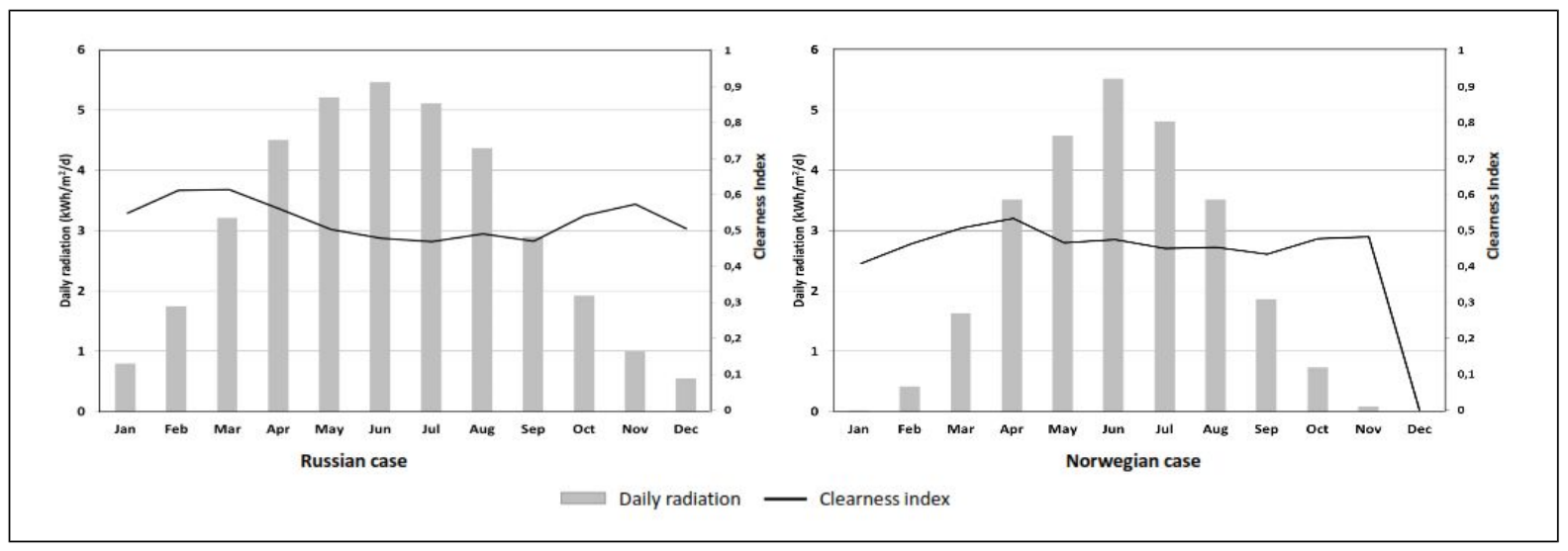

Fig. 6. a) Solar conditions for the Russian case (South of Yakutia, 56 $41^{\prime} \mathrm{N} ; 1^{\circ} 0^{\circ} 46^{\prime} \mathrm{E}$ ) and b)

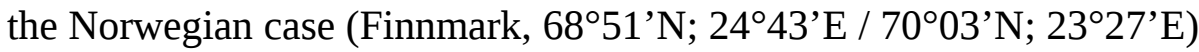

As it can be observed from Fig. 6, in the Norwegian case there is no available radiation in December. Months featuring the lowest available radiation of 0.55 and $0.02 \mathrm{kWh} / \mathrm{m}^{2} /$ day are December for the Russian case, and January for the Norwegian one. However, “dark days” may occur over the rest months of the year, and sometimes in strings of three to seven consecutive days (Table 3).

Table 3. The days with the minimum available insolation, $\mathrm{kWh} / \mathrm{m}^{2} /$ day in case study locations [35]

\begin{tabular}{|l|l|l|l|l|}
\hline Case & & \multicolumn{4}{|l|}{ The days with the minimum available insolation, $\mathrm{kWh} / \mathrm{m}^{2} / \mathrm{day}$} \\
\hline & & 1 day & 3 consecutive days & 7 consecutive days \\
\hline Russian case & January & 0.27 & 0.36 & 0.49 \\
\hline & $\begin{array}{l}\text { Novembe } \\
\mathrm{r}\end{array}$ & 0.07 & 0.30 & 0.38 \\
\hline & December & 0.36 & 0.37 & 0.38 \\
\hline Norwegian case & January & 0 & 0 & 0 \\
\hline & February & 0.06 & 0.09 & 0.17 \\
\hline & March & 0.02 & 0.45 & 0.70 \\
\hline & October & 0.02 & 0.21 & 0.24 \\
\hline & $\begin{array}{l}\text { Novembe } \\
\text { r }\end{array}$ & 0 & 0 & 0 \\
\hline & December & 0 & 0 & 0 \\
\hline
\end{tabular}


Svetlana V. Obydenkova and Joshua M. Pearce. Technical viability of mobile solar photovoltaic systems for indigenous nomadic communities in northern latitudes. Renewable Energy, 89,253-267 (2016). DOI:10.1016/j.renene.2015.12.036

Thus, while seasonal ratio of solar flux amounts to 9.93 (June/December, the Russian case) and to 13.3 (June/February, the Norwegian case), daily fluctuations during the "worst months" (minimum insolation/monthly average insolation) may reach up to 14.4 (November, the Russian case), 36.5 and 81.5 (in October and March, the Norwegian case).

The instances of a sudden solar condition change to the worst that may occur even over the months with a fairly high level of average insolation, especially when happening in a string of consecutive days, may become an issue for system sizing, as the latter is always designed for the worst scenario, and thus, might turn out to be oversized for the rest of time. For these scenarios a special schedule for such days is provided in detail below.

Albedo in boreal forests may vary greatly: from 0.2 for the grass to 0.75 for the grass covered by snow [37] and the albedo can significantly effect the performance of PV with different materials [38]. Since HOMER does not empower to consider monthly averaged surface albedo, the annual mean figure of 0.48 for both Russian and Norwegian cases was used year round in the simulation. This conservative assumption is based on the fact that in the Russian case there are 204 days with negative temperatures, in Norwegian about 212 days in the year so the albedo will vary.

Meteorological conditions in winter season for the chosen locations are fairly different, featuring a more extreme temperature in the south of Yakutia, and a milder one for the south of Finnmark, though for the both cases the coldest month is January, with the monthly average temperature of $-35^{\circ} \mathrm{C}$ and $-13.4^{\circ} \mathrm{C}$, and the average minimal temperature of $-39.1^{\circ} \mathrm{C}$ and $-17.2^{\circ} \mathrm{C}$, respectively, according to a 22-year period of observations (Fig. 7).

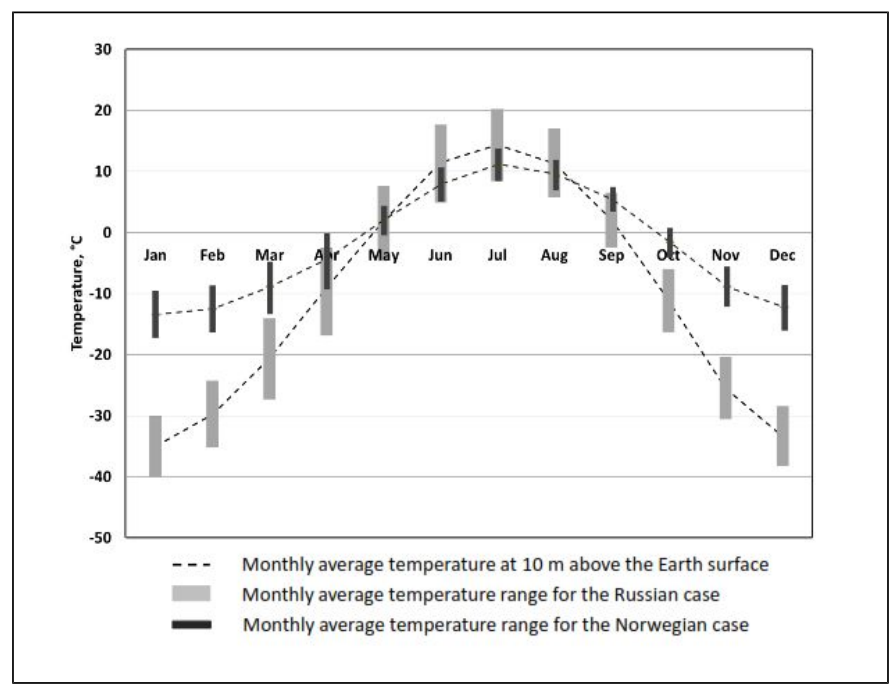

Fig. 7. Monthly averaged air temperature at $10 \mathrm{~m}$ above the surface of the Earth for the Russian case (South of Yakutia, 56 $41^{\prime} \mathrm{N}$; $120^{\circ} 46^{\prime} \mathrm{E}$ ) and the Norwegian case (Finnmark, 68 ${ }^{\circ} 51^{\prime} \mathrm{N}$; $24^{\circ} 43^{\prime} \mathrm{E} / 7^{\circ} 03^{\prime} \mathrm{N} ; 2^{\circ} 27^{\prime} \mathrm{E}$ ) 
Svetlana V. Obydenkova and Joshua M. Pearce. Technical viability of mobile solar photovoltaic systems for indigenous nomadic communities in northern latitudes. Renewable Energy, 89,253-267 (2016). DOI:10.1016/j.renene.2015.12.036

\subsubsection{Economic Data}

Since gasoline prices may have a significant impact on the system feasibility, this issue has been studied carefully.

According to the Russian Unified Interdepartmental Statistical Information System [39], the average purchase price of gasoline in Russia on May 1, 2015, was 0.556 \$US/L. However, in remote settlements, such as the village of Ust-Nukzha, the price may differ dramatically; community representatives claimed that they spent up to 0.86 \$US/L. Furthermore, the fuel uses to be delivered from the village of Ust-Nyukzha by small trucks, and usually in one or two, or, on a very rare occasion, in five cans of 50 liters each per one trip. Since there are no roads, the trucks, 4WD model GAZ 66 with gas consumption of $20 \mathrm{~L} / 100 \mathrm{~km}$ at the speed of $60 \mathrm{~km} / \mathrm{h}$, drive along frozen rivers, so the fuel can be delivered mainly in the winter season. Under such circumstances, the average final fuel cost delivered from the place of purchase to a camp may rise by $32 \%$, assuming a $125 \mathrm{~L}$ delivery during one truck trip.

According to Norway statistics [40], gasoline price amounted to 1.841 \$US/L on May 1, 2015.

For the period of 2013 - 2015, the average Russian rouble (RUB) and Norwegian krone (NOK) interest rates (IR) were reported at 16.5\% [41] and 13.3\% [42], respectively, where the latter one was attributed to a borrower operating in the renewable energy sector.

All RUB figures were converted into USD at the exchange rate fixed by the Central Bank of Russia [43] on the date given; conversion rates for NOK were derived from [44].

As to system component costs, taking into account that PV modules and batteries are delivered as a set (at least of two or more), components delivery costs for the both cases are put at $15 \%$ of the average market purchase price of the equipment.

\subsection{The System Modelling}

\subsubsection{The system components}

General information on system components used for the simulation is provided in Table 4.

\section{PV crystalline module}

For the Russian case, widely available 60 cells polycrystalline silicon PV modules HiSM250MG [45] were chosen with the module efficiency at standard test conditions (STC) of $15.5 \%$ and its dimensions of $1.65 \times 0.98 \times 0.035 \mathrm{~m}$. The community representatives confirmed that the module dimensions make it available for moving by reindeer sledges.

For Norwegian case, due to a large concern on mobility issue, the polycrystalline PV module with the module efficiency of $14.8 \%$ and of lesser dimensions $(1.32 \times 0.99 \times 0.05 \mathrm{~m})$ GEG-180P has been taken into simulation [46]. 
Svetlana V. Obydenkova and Joshua M. Pearce. Technical viability of mobile solar photovoltaic systems for indigenous nomadic communities in northern latitudes. Renewable Energy, 89,253-267 (2016). DOI:10.1016/j.renene.2015.12.036

The system has been simulated with a fixed $60^{\circ}$ tilt angle and operating temperature of the modules varies from $-40^{\circ} \mathrm{C}$ to $85^{\circ} \mathrm{C}$.

\section{Battery}

Lead-acid batteries have proven their reliability in extremely cold conditions at temperature of $-40^{\circ} \mathrm{C}$ and on remote installations, when they can experience very long deep discharge cycles [47]. This study along with conventional flooded lead-acid will focus on absorbent glass mat (AGM) valve-regulated lead-acid (VRLA) batteries, which benefit from acid spillage protection and gassing risk reduction, and are maintenance free. AGM batteries reveal better performance at low temperatures and, additionally, provide the possibility for flexible orientation [48, 49]. The latter may allow to consider this type of batteries for the mobile application in seasons when the electricity output becomes significantly excessive. Among the disadvantages, price seems to be the only one obvious weakness that still keeps VRLA behind flooded lead acid batteries on the market (120 \$US/kWh for AGM compare to 65 \$US/kWh for flooded [50]).

Taking into account the importance to provide both technically reliable and cost-effective solutions, several types of lead-acid batteries were considered, namely: 6V T-105 [51], deep cycle flooded and AGM designed 12 V 6FM100E-X [52]. The latter battery is not currently presented in the HOMER catalogue and was modelled based on manufacturer-provided data sheet [52].

As HOMER does not provide temperature effect on battery performance the approach based on the dependence of electrolyte freezing temperature on the state of charge (SOC) (only for the model T-105) has been applied. The data on the latter effect, derived from [49], were put over the minimal monthly average temperature, that revealed that for the Russian and Norwegian cases the battery should be kept above at least $79 \%$ and $52 \%$ of SOC, respectively, to prevent electrolyte from freezing.

\section{Inverter}

The models of the inverter selected were ERP900-12 and ERP400-12 [53], for both cases.

\section{$\underline{\text { Generator }}$}

Based on information provided by the Russian community representatives, a gasoline-powered generator model DDE GG950 DC [34] with the nominal capacity of $650 \mathrm{~W}$ was used for simulations (Table 4). Calculated generator electrical efficiency at maximal and half load amounts to $8.98 \%$ and $5.70 \%$, respectively. The generator has the temperature operational range of $-40^{\circ} \mathrm{C}$ to $40^{\circ} \mathrm{C}$.

For the Russian case, in the HOMER model the generator was scheduled to be optimized in the same evening hours as herders use to run it (6 - 11 p.m. in October - April, and $9-11$ p.m. in May - September); for the Norwegian case the generator was scheduled to be forced on in the 
Svetlana V. Obydenkova and Joshua M. Pearce. Technical viability of mobile solar photovoltaic systems for indigenous nomadic communities in northern latitudes. Renewable Energy, 89,253-267 (2016). DOI:10.1016/j.renene.2015.12.036

same evening hours during January, November and December (to avoid the battery bank oversizing), and to be optimized during the rest of months.

Table 4. The system components

\begin{tabular}{|c|c|c|c|c|c|c|c|c|}
\hline \multicolumn{9}{|c|}{ PV crystalline module } \\
\hline Model & Type & $\begin{array}{c}\text { Nomina } \\
\text { l } \\
\text { output, } \\
\text { W }\end{array}$ & \multicolumn{2}{|c|}{$\begin{array}{c}\text { Voltage } \\
\text { (V)/ } \\
\text { current } \\
\text { (A) at } \\
\text { Pmax }\end{array}$} & $\begin{array}{c}\text { Module } \\
\text { efficienc } \\
\text { y, \% }\end{array}$ & $\begin{array}{c}\text { Approx. } \\
\text { weight, } \\
\mathrm{kg}\end{array}$ & $\begin{array}{l}\text { Dimensions } \\
\text { (Length } \times \\
\text { Width } \times \\
\text { Height), m }\end{array}$ & $\begin{array}{l}\text { Approx. } \\
\text { purchase } \\
\text { cost, U.S. } \\
\$^{(a)}\end{array}$ \\
\hline $\begin{array}{l}\text { HiS- } \\
\text { M250MG }\end{array}$ & \multirow[t]{2}{*}{$\begin{array}{l}\text { Poly- } \\
\text { crystalli } \\
\text { ne }\end{array}$} & \multirow[t]{2}{*}{250} & \multicolumn{2}{|l|}{ 30.9/8.1 } & 15.5 & 19 & $\begin{array}{l}1.65 \times 0.98 \times 0.03 \\
5\end{array}$ & 250 \\
\hline GEG-180P & & & \multicolumn{2}{|c|}{$24.1 / 7.47$} & 15 & 16.4 & $1.32 \times 0.99 \times 0.05$ & 120 \\
\hline \multicolumn{9}{|l|}{ Battery } \\
\hline Model & \multicolumn{2}{|l|}{ Type } & $\begin{array}{c}\text { Nominal } \\
\text { voltage, } \mathrm{V}\end{array}$ & \multicolumn{2}{|c|}{$\begin{array}{c}\text { Nominal } \\
\text { capacity, } \\
\text { Ah }\end{array}$} & $\begin{array}{l}\text { Approx. } \\
\text { weight, } \\
\text { kg }\end{array}$ & $\begin{array}{c}\text { Dimensions } \\
\text { (Length } \times \text { Width } \\
\times \text { Height }), \mathrm{m}\end{array}$ & $\begin{array}{c}\text { Approx. } \\
\text { purchase } \\
\text { cost, U.S. } \\
\$^{(\mathrm{a})}\end{array}$ \\
\hline $\mathrm{T}-105$ & \multicolumn{2}{|l|}{\begin{tabular}{|l} 
Lead-acid \\
flooded
\end{tabular}} & 6 & \multicolumn{2}{|l|}{225} & 28 & $0.26 \times 0.18 \times 0.28$ & 160 \\
\hline $\begin{array}{l}\text { 6FM100E- } \\
X\end{array}$ & \multicolumn{2}{|l|}{\begin{tabular}{|l} 
Lead-acid \\
AGM
\end{tabular}} & 12 & \multicolumn{2}{|l|}{100} & 29 & $0.33 \times 0.17 \times 0.22$ & 300 \\
\hline \multicolumn{9}{|l|}{ Generator } \\
\hline \multirow[t]{2}{*}{ Model } & Type & $\begin{array}{c}\text { Nomina } \\
\text { l } \\
\text { output, } \\
\text { W } \\
\end{array}$ & \multicolumn{3}{|c|}{$\begin{array}{l}\text { Fuel } \\
\text { sumption at } \\
\text { erent loads, } \\
\text { l/h } \\
\end{array}$} & $\begin{array}{l}\text { Approx. } \\
\text { weight, } \\
\text { kg }\end{array}$ & $\begin{array}{c}\text { Dimensions } \\
\text { (Length } \times \text { Width } \\
\times \text { Height }), \mathrm{m}\end{array}$ & $\begin{array}{l}\text { Approx. } \\
\text { purchase } \\
\text { cost, U.S. } \\
\$^{\text {(a) }}\end{array}$ \\
\hline & & & $\begin{array}{c}100 \\
\%\end{array}$ & $\begin{array}{l}75 \\
\% \\
\end{array}$ & $\begin{array}{l}50 \\
\%\end{array}$ & & & \\
\hline $\begin{array}{l}\text { DDE } \\
\text { GG950 DC }\end{array}$ & $\begin{array}{l}\text { Gasoline- } \\
\text { fired, } 2 \\
\text { stroke } \\
\end{array}$ & 650 & 0.8 & 0.7 & $\begin{array}{l}0.6 \\
3\end{array}$ & 18.5 & $0.39 \times 0.33 \times 0.34$ & 150 \\
\hline \multicolumn{9}{|l|}{ Inverter } \\
\hline Model & $\begin{array}{l}\text { Continu } \\
\text { ed } \\
\text { power, } \\
\text { W }\end{array}$ & \begin{tabular}{|l|} 
Input \\
DC \\
voltage \\
range, \\
V \\
\end{tabular} & $\begin{array}{l}\text { Output } \\
\text { voltage } \\
\text {, V }\end{array}$ & $\begin{array}{l}\text { Effic } \\
\text { y, \% }\end{array}$ & cienc & $\begin{array}{l}\text { Approx. } \\
\text { weight, } \\
\text { kg }\end{array}$ & $\begin{array}{l}\text { Dimensions } \\
\text { (Length } \times \text { Width } \\
\times \text { Height }), \mathrm{m}\end{array}$ & $\begin{array}{l}\text { Approx. } \\
\text { purchase } \\
\text { cost, U.S. } \\
\$^{\text {(a) }}\end{array}$ \\
\hline $\begin{array}{l}\text { ERP1100- } \\
12\end{array}$ & 900 & $10-15$ & 220 & 90 & & 2.7 & $\begin{array}{l}0.23 \times 0.15 \times \\
0.07\end{array}$ & 90 \\
\hline ERP900-12 & 400 & $10-15$ & 220 & 90 & & 2.25 & $\begin{array}{l}0.19 \times 0.05 \times \\
0.13\end{array}$ & 40 \\
\hline
\end{tabular}


Svetlana V. Obydenkova and Joshua M. Pearce. Technical viability of mobile solar photovoltaic systems for indigenous nomadic communities in northern latitudes. Renewable Energy, 89,253-267 (2016). DOI:10.1016/j.renene.2015.12.036

\subsubsection{Electric Load Profile}

Incandescent lamps and LED have been used for the simulation. 8W LEDs are able to provide equivalent illumination to a $60 \mathrm{~W}$ incandescent lamp were selected for the high efficiency case.

To avoid battery oversizing the load schedule should be alternating, allowing more appliances to be charged during the light time when solar radiation reaches its maximum values. For this purpose, laptops and washing machines were scheduled to be charged or run in the daytime, while phones were scheduled to be charged during the night time (Table 5). Such approach may be quite viable for reindeer herders as some persons are always present in a nomadic camp during daytime, usually women, herders’ wives [30].

In the Norwegian case, given the critical shortage of insolation in January, November and December, that makes generator use unavoidable, the appliances for those three months were scheduled to be charged during evenings, as herders currently do.

As it was observed above, the months of January, November and December for the Russian case and February, March and October for the Norwegian case feature poor insolation during strings of days, thus imposing constraints on PV output and the battery bank available capacity. This, in its turn, may prompt HOMER to consider a higher PV or/and battery bank size. For the Russian case there use to be four, seven and nine such unfavorable days in January, November and December, respectively, and for the Norwegian case they are 15 days in February, three days in March and 9 days in October. For those days separate scenario has been simulated (abbr. "XXXSch”), where only laptops and video players are not allowed to charge. This does not compromise people's security, as all communication devices and other appliances are left to be charged as usual. In practice, this can be achieved if, during mentioned months, laptops and video players are allowed to be charged only under favorable solar conditions, when those are observed by camp people.

Table 5. Usual load schedule

\begin{tabular}{|l|c|c|}
\hline Time & \multicolumn{2}{|c|}{ Appliances } \\
\hline & $\begin{array}{c}\text { Winter season (except for January, November } \\
\text { and December in Norwegian case) }\end{array}$ & Summer season \\
\hline Weekdays & Satellite and mobile phones (charging and standby) \\
\hline $00-07$ & Laptops and video-players (charging) \\
\hline $11-13$ & Lamps & - \\
\hline $18-19$ & Lamps & - \\
\hline $19-20$ & Lamps & Lamps \\
\hline $20-21$ & Lamps & Lamps \\
\hline $21-22$ & Lamps \\
\hline $22-23$ & Satellite and mobile phones (charging and standby) \\
\hline $23-24$ & \multicolumn{2}{|c|}{} \\
\hline Weekends & Satellite and mobile phones (charging and standby) \\
\hline $00-07$ &
\end{tabular}


Svetlana V. Obydenkova and Joshua M. Pearce. Technical viability of mobile solar photovoltaic systems for indigenous nomadic communities in northern latitudes. Renewable Energy, 89,253-267 (2016). DOI:10.1016/j.renene.2015.12.036

\begin{tabular}{|l|c|c|}
\hline Time & \multicolumn{2}{|c|}{ Appliances } \\
\hline & $\begin{array}{c}\text { Winter season (except for January, November } \\
\text { and December in Norwegian case) }\end{array}$ & Summer season \\
\hline $11-13$ & Laptops and video-players (charging) \\
\hline $13-14$ & Washing machines \\
\hline $18-19$ & Lamps & - \\
\hline $19-20$ & Lamps & - \\
\hline $20-21$ & Lamps & Lamps \\
\hline $21-22$ & Lamps & Lamps \\
\hline $22-23$ & Lamps \\
\hline $23-24$ & Satellite and mobile phones (charging and standby) \\
\hline
\end{tabular}

\subsubsection{Variables for sensitivity analysis}

As crystalline PV module prices have been gradually decreasing since 2001, with the average decline of about $7.6 \%$ over the last 14 years [54] shown, the most evident decrease of $0.54 \%$ per year should be taken for sensitivity analysis for the next ten years.

Lead showed large oscillations in price over the last ten years along with other commodities. According to Bloomberg [44], the lead price was relatively steady since 2013, but since June, 2014 till June, 2015 the price fell by 13\%. However, it is supposed not to influence prices for finished batteries too much, as back in 2005, for instance, a three-fold jump in lead price vs. 2002 resulted in a mere 22\% growth of finished battery price, witnessing its relatively low elasticity to raw costs [55]. Given this, battery prices have not been taken for the sensitivity analysis.

What concerns gasoline prices, they were taken at the historical minimum and maximum figures over 2013 - 2015, of 0.94 and 1.63 \$US per liter and 1.78 and 2.47 \$US for the Russian [39] and Norwegian [40] cases, respectively.

RUB interest rates (IR) for small businesses has been dramatically varying over the last two years from $12.7 \%$ to $38.1 \%$ [41] (one-year loans), where the latter indicates the crisis situation in the Russian economic environment. For the Norwegian case, IR within the renewable segment of borrowers has been fluctuating roughly between $8.3 \%$ and $19.9 \%$ (three-year NOK bonds) [42]. The named figures have been used in the sensitivity analysis._

\section{Results and Discussion}

There are several most obvious issues to be analyzed taking into account the project's special features and challenges. Among them are (i) the remote PV system competitiveness with conventional energy supply scheme in northern latitudes, (ii) significant fluctuation of solar radiation over a year affecting the system size, (iii) predictable decrease of power output during the system lifetime that can force the camp to strength PV or battery bank capacity in $10-20$ 
Svetlana V. Obydenkova and Joshua M. Pearce. Technical viability of mobile solar photovoltaic systems for indigenous nomadic communities in northern latitudes. Renewable Energy, 89,253-267 (2016). DOI:10.1016/j.renene.2015.12.036

years, (iv) the role of albedo effect on power output and benefits of thin-film PV implementation, (v) PV system behavior under different economic conditions, and (vi) the system portability .

\subsection{The remote PV system competitiveness in northern latitudes}

While analyzing the system competitiveness, net present cost (NPC) is used as the economic indicator, which is based on the concept of money that is owned or spent today is worth more than those that are to be received, owned or spent in the future. Future cash flows are eroded by inflation, and as they cannot be put to work immediately, the loss of benefit from their potential use is incurred. To evaluate the current value of future money, expected cash flows are discounted using an annual interest rate (IR). When such future payments are to be effected in the framework of a project, the result of the named calculation, or the sum of such results, is NPC of a system. It is 'net' because future spending in that case is the balance of all related cash flows.

Optimization results based on system NPC have revealed that at a given gasoline prices on-site and generator in use, a PV-based system is competitive compared to fuel-based ones to power nomadic camp in all considered scenarios (Fig. 8). As it can be observed from Table 6, while PV-based system configurations with incandescent lamps are 1.5 (RH1), 2.46 (RL1), 1.8 (NH1) and 3.3 (NL1) times more cost-efficient than solely generator based configurations, the LED lighting scenarios ensure a drop in NPC of up to 3.6 (RH2), 5.4 (RL2), 3.9 (NH2) and 5.1 (NL2) times compared to solely fuel-based systems.

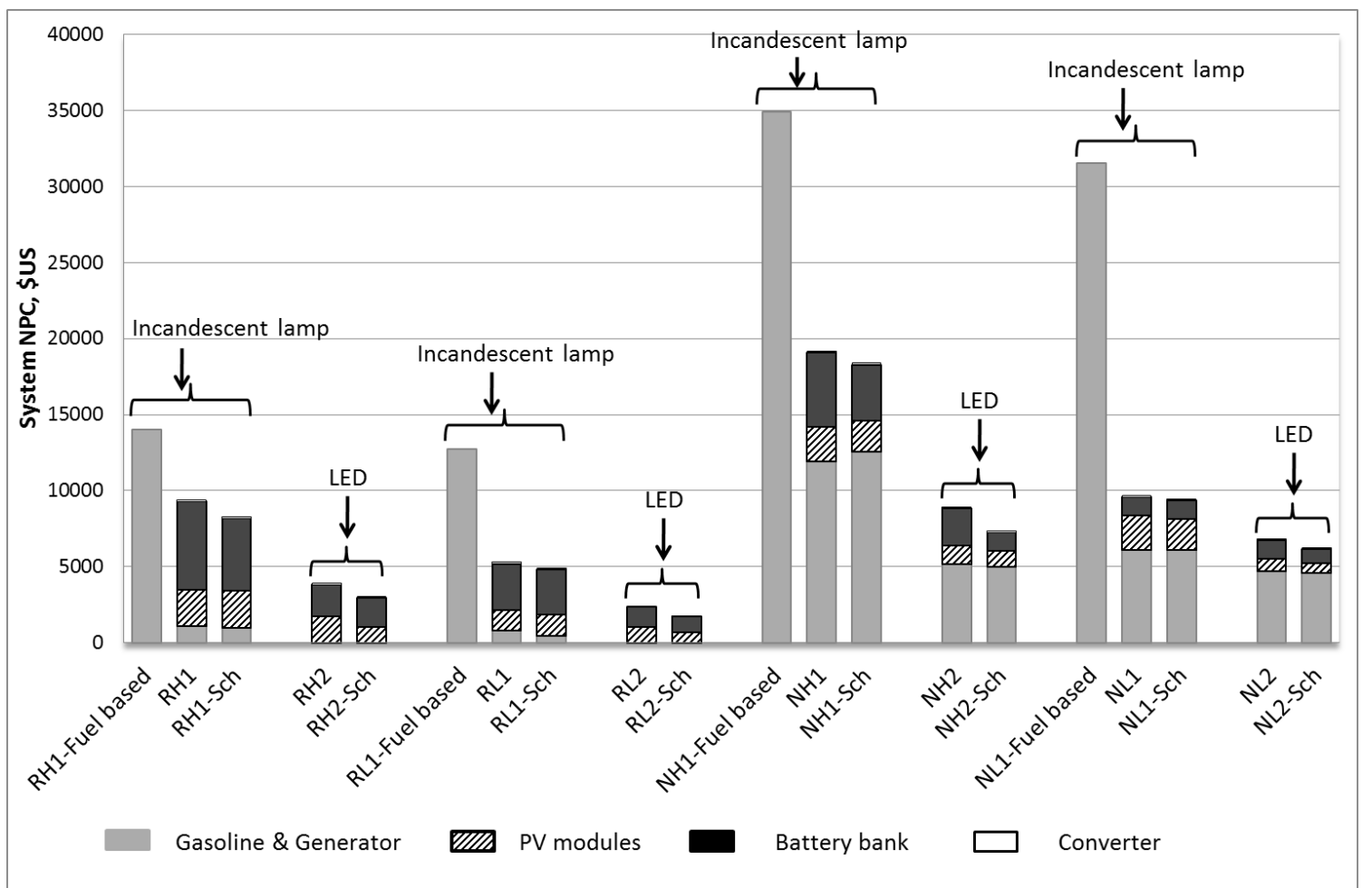

Fig. 8. The system configuration for different scenarios vs. NPC 
Svetlana V. Obydenkova and Joshua M. Pearce. Technical viability of mobile solar photovoltaic systems for indigenous nomadic communities in northern latitudes. Renewable Energy, 89,253-267 (2016). DOI:10.1016/j.renene.2015.12.036

However, while the most effective configuration data clearly demonstrates the PV-based system disadvantage when powering incandescent lights (scenarios RH1, RH1-Sch, RL1, RL1-Sch, NH1, NH1-Sch, NL1, NL1-Sch), the PV-based systems targeted to serve camps with LED lighting can be deemed more appropriate for portable application (Table 6). Hence, scenarios based on incandescent lamps were eliminated from the further evaluation.

Depending on the load, capacity of PV modules / battery bank required for the nomadic camp may vary from $0.5 \mathrm{~kW} / 2.4 \mathrm{kWh}$ (RL1-Sch) to $1.08 \mathrm{~kW} / 10.08 \mathrm{kWh}$ (NH2), where the latter example represents the scenario where the camp over the period from February to November is served almost entirely by PV, with only two gen-set starts in February (Table 6).

Table 6. The most beneficial system configuration vs. scenario, simulated in HOMER

\begin{tabular}{|c|c|c|c|c|c|}
\hline \multirow[t]{2}{*}{ Scenario } & \multicolumn{3}{|c|}{ The most competitive configuration } & \multirow{2}{*}{$\begin{array}{l}\text { Gasoline } \\
\text { consumpti } \\
\text { on, L/year }\end{array}$} & \multirow[t]{2}{*}{ NPC, US\$ } \\
\hline & $\begin{array}{l}\mathrm{PV}, \\
\mathrm{kW}\end{array}$ & Battery & $\begin{array}{c}\text { Generator } \\
\text { (GG950), kW }\end{array}$ & & \\
\hline \multicolumn{6}{|c|}{ Russian case } \\
\hline RH1 & 1.75 & $10 \times 6 \mathrm{FM} 100 \mathrm{E}-\mathrm{X}$ & 1.3 & 108 & 9,359 \\
\hline RH1-Sch & 1.75 & $6 \times 6$ FM100E-X & 0.65 & 121 & 8,240 \\
\hline RH2 & 1.25 & $5 \times 6$ FM100E-X & - & - & 3,904 \\
\hline RH2-Sch & 0.75 & $4 \times 6$ FM100E-X & - & - & 3,045 \\
\hline RL1 & 1 & $5 \times 6 F M 100 E-X$ & 1.3 & 65 & 5,288 \\
\hline RL1-Sch & 1 & $5 \times 6$ FM100E-X & 0.65 & 41 & 4,871 \\
\hline RL2 & 0.75 & $3 \times 6$ FM100E-X & - & - & 2,328 \\
\hline RL2-Sch & 0.5 & $2 \times 6$ FM100E-X & - & - & 1,752 \\
\hline \multicolumn{6}{|c|}{ Norwegian case } \\
\hline NH1 & 1.98 & $16 \times \mathrm{T}-105$ & 1.3 & 677 & 19,157 \\
\hline NH1-Sch & 1.8 & $12 \times \mathrm{T}-105$ & 1.3 & 713 & 18,360 \\
\hline NH2 & 1.08 & $8 \times \mathrm{T}-105$ & 0.65 & 291 & 8,920 \\
\hline NH2-Sch & 0.9 & $4 \times \mathrm{T}-105$ & 0.65 & 281 & 7,327 \\
\hline NL1 & 1.98 & $4 \times \mathrm{T}-105$ & 0.65 & 345 & 9,648 \\
\hline NL1-Sch & 1.8 & $4 \times \mathrm{T}-105$ & 0.65 & 346 & 9,448 \\
\hline NL2 & 0.72 & $4 \times \mathrm{T}-105$ & 0.65 & 264 & 6,877 \\
\hline NL2-Sch & 0.54 & $2 \times 6$ FM100E-X & 0.65 & 257 & 6,435 \\
\hline
\end{tabular}

Under the current economic situation and gasoline prices on-site, the most competitive system configurations in the Russian case rely solely on PV as energy source (Fig. 8), while all the Norwegian case scenarios are fuel dependent due to the critical shortage of solar insolation 
Svetlana V. Obydenkova and Joshua M. Pearce. Technical viability of mobile solar photovoltaic systems for indigenous nomadic communities in northern latitudes. Renewable Energy, 89,253-267 (2016). DOI:10.1016/j.renene.2015.12.036

during three months (November, December and January), and, however, are fuel-independent during the rest months (except for mentioned above scenario NH2).

The amount of fuel required currently for a high and a low energy-intensive camps do not differ substantially and amount to 1927 and 1736 l/year, respectively, that may happen due to extremely inefficient gen-sets used, especially at the load under nominal generator's capacity. Those figures may be translated into 13.9 - 15.4 vehicle trips per year required to deliver the necessary fuel to the camp.

If LED lighting powered by PV is chosen, the amount of fuel required for the Norwegian case would decrease by about 6.7 times from the current figure, that again may imply merely $2.0-2.3$ vehicle trips a year for the fuel delivery, and, as it was mentioned above, the use of PV as energy source for the Russian case would free the camps from the dependence on fuel supplies for the entire year.

As for the type of battery preferred, as it was discussed in chapter 3.2.1, to prevent electrolyte freezing flooded lead acid battery (T-105) must be kept above at least 52\% of SOC for the Norwegian case and 79\% of SOC for the Russian one, that, obviously, decrease available battery capacity. However, even though, this type of battery have been selected in the optimization process (so, by HOMER) as more cost efficient for Norwegian case than AGM battery. In the Russian case, where the average minimal temperature may drop to $-39.1^{\circ} \mathrm{C}$, more expensive, however performing better under cold environment, AGM battery has been chosen beneficial compare to flooded lead acid battery.

\subsection{Fluctuation of solar conditions}

The most obvious challenge for a PV system deployed in northern latitudes is significant fluctuation of solar insolation during the year that might affect the PV system size and, hence, its economics [13]. However, while the overall seasonal system oversizing is a given inevitability, there exists another issue related to the daily oversizing that might be treated with more success.

If the system performance is considered in terms of solely primary energy source (i.e. PV output), without backup from battery bank, then it is sized based on the days with the maximum deficit of solar insolation $\left(0.02\right.$ and $0.07 \mathrm{kWh} / \mathrm{m}^{2} /$ day for Norwegian and Russian cases, respectively), provided electricity excess during the rest of time. The system evaluation in terms of solely battery bank with minimum of energy input would reveal that the battery is sized dependent on load duration that, in its turn, referred to a period of consecutive days with the highest deficit of solar insolation. Thus, special scheduling for the appliances charging over those days (1, 3 and 7 consecutive days) may play a significant role in the system sizing.

The simulation of separate scenarios when laptops and video players were not allowed to be charged during strings of dark days, 20 and 27 days for the whole year in the Russian and the Norwegian cases, respectively, while keeping the usual schedule for the rest of appliances, revealed that the decrease in PV module and battery bank capacity would amount on average to 1.6 and 1.4 times in the Russian case, and 1.3 and 1.9 in Norwegian case respectively (Table 7). 
Svetlana V. Obydenkova and Joshua M. Pearce. Technical viability of mobile solar photovoltaic systems for indigenous nomadic communities in northern latitudes. Renewable Energy, 89,253-267 (2016). DOI:10.1016/j.renene.2015.12.036

Table 7. Impact of the daily load optimization on the system capacity

\begin{tabular}{|c|c|c|c|c|c|c|c|c|c|}
\hline & RH2 & $\begin{array}{l}\text { RH2- } \\
\text { Sch }\end{array}$ & RL2 & $\begin{array}{l}\text { RL2- } \\
\text { Sch }\end{array}$ & NH2 & $\begin{array}{l}\text { NH2- } \\
\text { Sch }\end{array}$ & NL2 & $\begin{array}{l}\text { NL2- } \\
\text { Sch }\end{array}$ \\
\hline \multicolumn{2}{|l|}{ PV capacity, kW } & 1.25 & 0.75 & 0.75 & 0.5 & 1.08 & 0.9 & 0.72 & 0.54 \\
\hline \multicolumn{2}{|c|}{$\begin{array}{l}\text { Available battery bank } \\
\text { capacity, kWh (above min. } \\
\text { SOC) }\end{array}$} & 3.60 & 2.88 & 2.16 & 1.44 & 5.18 & 2.59 & 2.59 & 1.44 \\
\hline Electricity excess & $\%$ & 68.6 & 48.7 & 68.8 & 56.7 & 54.9 & 50.7 & 63.0 & 54.3 \\
\hline & kWh/year & $\begin{array}{l}1,14 \\
8\end{array}$ & 489 & 665 & 379 & 636 & 496 & 485 & 324 \\
\hline
\end{tabular}

Electricity excess in the system has the evident reference to the system oversizing. The load optimization for 20 and 27 most unfavorable days in the Russian and the Norwegian cases, respectively, results in the decrease of annual electricity excess in the system of up to $19.9 \%$ (RH2-Sch), 12.1\% (RL2-Sch), 4.2\% (NH2-Sch) and 8.7\% (NL2-Sch) compare to scenariosancestors. The systems seem have obtained their optimal size at the used load profile, as there are almost no excesses of electric power over the months featuring the shortage of solar radiation, as well as a harvest of a peak electricity excess can be observed over summer months (Fig. 9).Since the scenarios with optimized schedule require lesser PV and battery bank capacity (Table 7), this, in its turn, results in economic benefits. The systems with special load schedule are as much as $22.0 \%$ (RH2-Sch), $26.4 \%$ (RL2-Sch), 17.8\% (NH2-Sch) and 8.5\% (NL2-Sch) more cost-efficient than their precursors (Figure 8). A lesser pronounced decrease of system NPC in Norwegian case is explained by its inherent dependence on fuel during three "dark months".

In spite of results obtained, and since HOMER allows neither to optimize the daily load depending on solar conditions, nor to create a daily schedule for system components (e.g. for the generator that could be forced on solely during the strings of "dark days"), the optimal load and components schedule based on the periods of consecutive "dark days" must be established with the use of numerical optimization approaches, e.g. in the SCILAB. 
Svetlana V. Obydenkova and Joshua M. Pearce. Technical viability of mobile solar photovoltaic systems for indigenous nomadic communities in northern latitudes. Renewable Energy, 89,253-267 (2016). DOI:10.1016/j.renene.2015.12.036

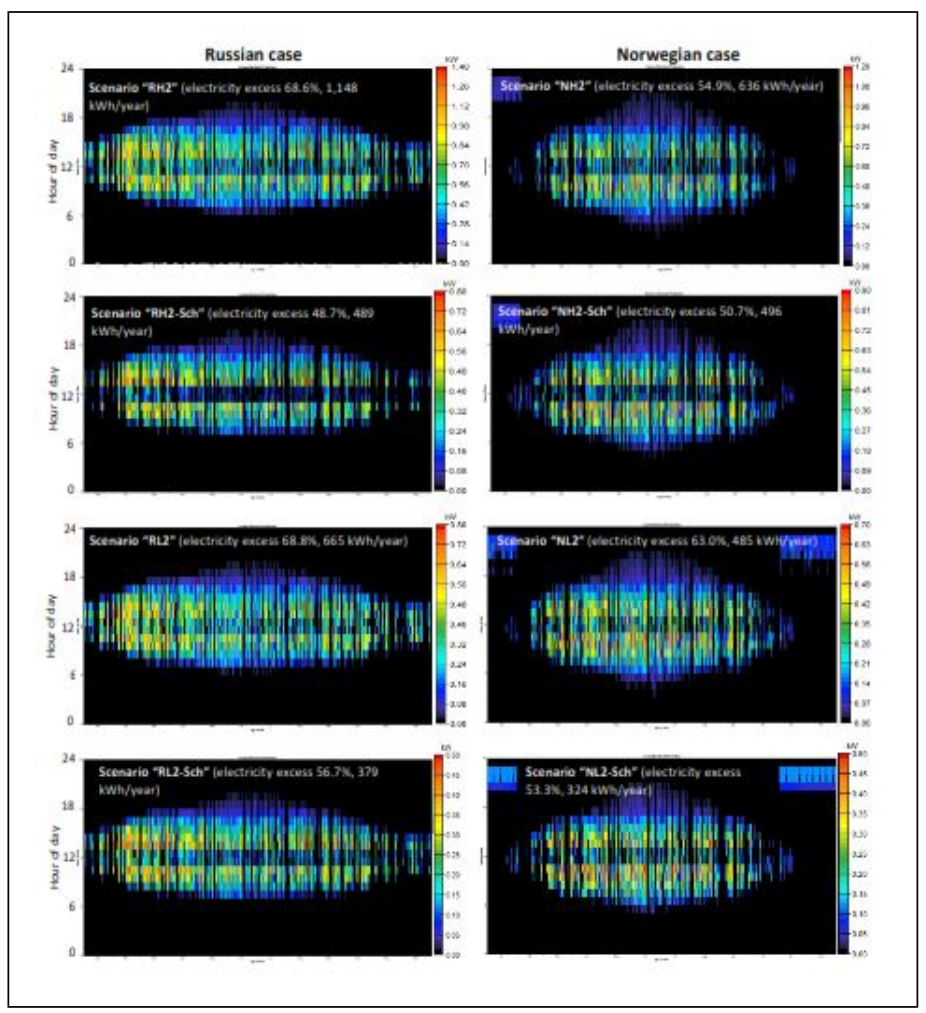

Fig. 9. Excess electrical production

\subsection{Decrease of power output during the system lifetime}

The other issue examined was the system warranted power after 10 and 20 years of the project lifetime, which was set to be reduced by 10 and $20 \%$ from the declared nominal output, respectively. This analysis revealed that in all scenarios, PV modules deliver sufficient power to serve the camp electric needs during the whole project lifetime, neither requiring changes to the system configuration, nor forcing the system to use gasoline as a backup. In the scenario NH2Sch the drop in the module efficiency by $10 \%$ and $20 \%$ forces the system to run the generator once in the last day of October with fuel consumed for this purpose of $1 \mathrm{~L}$.

\subsection{The role of albedo for northern locations}

The system configuration is defined by days featuring a critical shortage of solar insolation occurring mainly over winter months, when albedo reaches its maximal value of 0.75 . Given this, a sensitivity analysis of the dependence of the system configuration on the albedo effect showed a change of the level of ground reflectance from 0.48 to 0.75 in the scenario RH2 reduces PV capacity from $1.25 \mathrm{~kW}$ to $1 \mathrm{~kW}$, however requiring two generator starts with the total fuel consumption of $7 \mathrm{~L}$ /year compared to no fuel use. For the other scenarios, even though albedo does not impact the system configuration, it contributes to more energy supplied to the 
Svetlana V. Obydenkova and Joshua M. Pearce. Technical viability of mobile solar photovoltaic systems for indigenous nomadic communities in northern latitudes. Renewable Energy, 89,253-267 (2016). DOI:10.1016/j.renene.2015.12.036

system during the most critical days, keeping the battery bank at a higher SOC, thereby increasing batteries lifetime and, ultimately, reducing the system cost (Fig. 10), although negligibly (by one US dollar to US\$20).

Since the effect of ground reflectance influencing different system features has displayed a certain impact on the system design, this matter must be treated more carefully, especially in terms of applying it to several types of thin-film PV, where the effect of spectrally responsive albedo for, for instance, hydrogenated amorphous silicon might be anticipated at higher values of up to 0.94 [38].

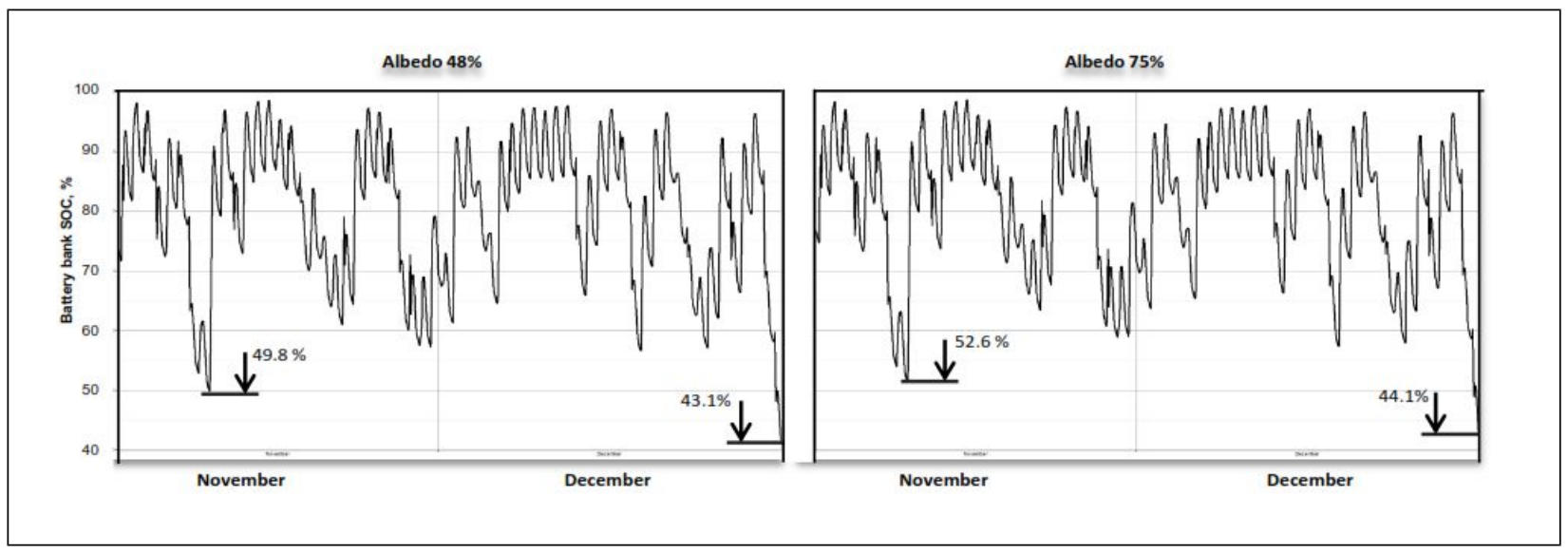

Fig. 10. Scenario RL2-Sch: the battery bank SOC in November and December at the levels of surface albedo of $48 \%$ and $75 \%$. The minimal SOC for used battery is $40 \%$.

\subsection{PV system behavior under different economic conditions}

In the Russian scenarios (RH2, RH2-Sch, RL2 and RL2-Sch), a 5.4\% decrease in prices for PV modules results in a roughly 1.8\% (RH2 and RL2), 1.4\% (RH2-Sch) and 1.7\% (RL2-Sch) NPC drop. The lesser impact of the PV module prices is expected for the Norwegian case, since the system still relies on fuel during three months (November, December and January). Since that, a drop in the system NPC stemming from a 5.4\% decrease in PV module price is expected at the level of $0.5 \%$ (NH2, NH2-Sch), $0.4 \%$ (NL2) and $0.3 \%$ (NL2-Sch) (Fig. 11). A very similar situation is being observed under different economic conditions in the both countries. This indicates that the other component, namely battery plays the crucial role in the system NPC.

The system configuration under the different economic conditions remains basically the same, with the only exception for the scenarios RH2 and RH2-Sch. Under crisis conditions in Russia (IR of 38.1\%) the optimized system would prefer to rely on a lesser battery bank capacity, by 1.2 $\mathrm{kWh}$, and on higher PV capacity, by $0,25 \mathrm{~kW}$, though serve a part of electric needs from generator backup with insignificant total fuel consumption of 11 - $12 \mathrm{~L} /$ year. 
Svetlana V. Obydenkova and Joshua M. Pearce. Technical viability of mobile solar photovoltaic systems for indigenous nomadic communities in northern latitudes. Renewable Energy, 89,253-267 (2016). DOI:10.1016/j.renene.2015.12.036

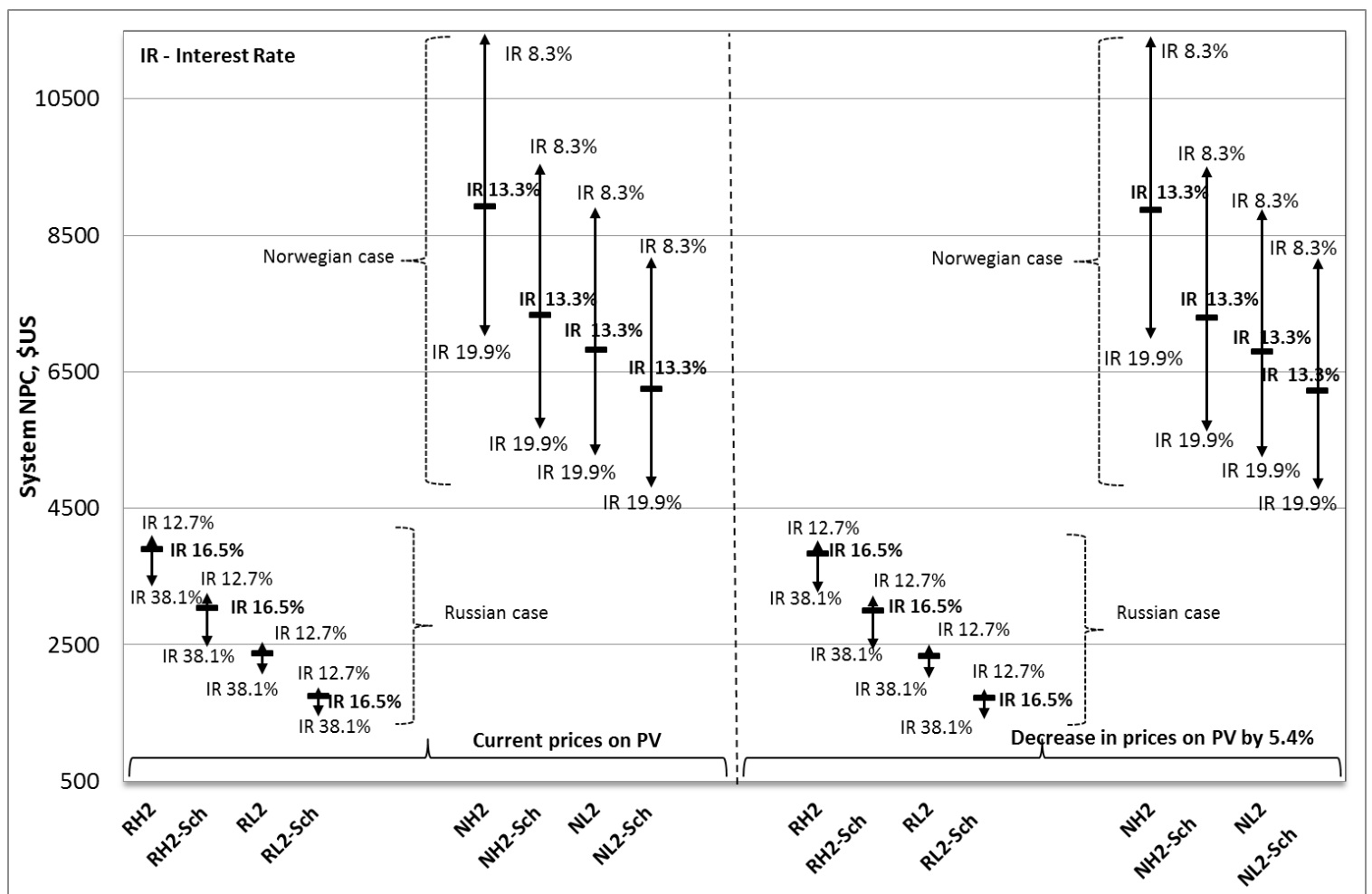

Fig. 11. The system NPC under different interest rates (IR), at current prices on PV modules and at their drop of $5.4 \%$

As for fuel price, the only the Norwegian case is subject to fluctuations, since all LED-based Russian scenarios rely on PV+battery system as the most economically effective system configuration, even at the minimal cost of gasoline of $0.943 \$ / \mathrm{L}$, including all delivery fees. The situation remains basically the same under different IR. For the Norwegian case, fluctuations in fuel prices affects the system NPC as fuel expenses rise or decrease, however, it does not influence neither system configuration, nor the amount of fuel consumed at different IR.

\subsection{System portability}

As one of the most critical parameters is system component dimensions making them suitable for sledge transportation (Section 3.2.1), the system weight is the other issue to be discussed within the assessment of the system feasibility.

Approximate weight of a PV-based system required to power the more energy intensive camp is almost twice as much as that of the system necessary for the low energy intensive (Table 8), however the figures provided do not include system support structure. The larger system weight in the Norwegian case compared to the Russian one is almost entirely due to PV modules. The latter were chosen of a lesser dimensions, however, while the ratio of PV module weight to PV module capacity for the Russian case amounts to $76 \mathrm{~kg} / \mathrm{kW}$, the same ratio for the Norwegian case would be $91.1 \mathrm{~kg} / \mathrm{kW}$.

Table 8. The system weight 
Svetlana V. Obydenkova and Joshua M. Pearce. Technical viability of mobile solar photovoltaic systems for indigenous nomadic communities in northern latitudes. Renewable Energy, 89,253-267 (2016). DOI:10.1016/j.renene.2015.12.036

\begin{tabular}{|l|l|l|}
\hline \multicolumn{1}{|c|}{ Scenario } & \multicolumn{2}{c|}{ The weight of the system } \\
\hline & \multicolumn{1}{|c|}{ Total, $\mathrm{kg}$} & \multicolumn{1}{c|}{$\begin{array}{c}\text { Specific, } \\
\mathrm{kg} / \text { person }\end{array}$} \\
\hline RH2 & 242.7 & 15.17 \\
\hline RH2-Sch & 175.7 & 10.98 \\
\hline RL2 & 146.3 & 8.60 \\
\hline RL2-Sch & 98.7 & 5.81 \\
\hline NH2 & 325.1 & 20.32 \\
\hline NH2-Sch & 196.7 & 12.29 \\
\hline NL2 & 180.3 & 10.61 \\
\hline NL2-Sch & 107.5 & 6.32 \\
\hline
\end{tabular}

Since strict criteria of where the system to be portable or not, in terms of its weight, are not defined, they are up to herdsmen decision. Since that, the system's quite high expected weight for more energy intensive camp or scenario without applying of an optimized schedule (RH2, RH2-Sch, NH2, NH2-Sch and NL2) should push to consider based on flexible substrate thin-film $\mathrm{PV}$ as a more reasonable energy source for those nomadic dwellings, while the system weight for camp with lower energy consumption (RL2, RL2-Sch, NL2-Sch) seems acceptable for portable application.

\section{Conclusions}

This paper investigated the technical viability of using photovoltaic system for nomadic camps of reindeer herders in remote in taiga or tundra under extreme northern conditions. The results on case studies in Russia and Norway showed that under current conditions, PV systems are economically beneficial. The results also showed that all incandescent lamps should be replaced by LEDs in such camps to improve portability of the PV systems as well as the economics. Competitive PV-based system configurations with incandescent lights are up to three times more cost efficient than configurations relying solely on fuel; while LED lighting coupled with PVbased systems is more than five times as cost-beneficial, as systems currently in use.

As the minimal temperature for the Norwegian location is at least twice as high as in Russia, HOMER simulate showed it is beneficial to use more expensive AGM batteries in the Russian case and less-expensive flooded lead acid battery in Norway. While system oversizing due to seasonal solar flux fluctuation for chosen locations cannot be avoided, changing behaviors can be used to minimize the effect on PV system design. Similarly the effects of surface albedo are minimal.

The decrease in PV prices results in a system NPC drop that is more pronounced for the Russian case than for the Norwegian case, which is dependent on fuel during three months. Fluctuations in fuel prices in both the Norwegian and the Russian cases do not affect materially the system configuration or the amount of fuel consumed. For the interest rates studied, which in both case 
Svetlana V. Obydenkova and Joshua M. Pearce. Technical viability of mobile solar photovoltaic systems for indigenous nomadic communities in northern latitudes. Renewable Energy, 89,253-267 (2016). DOI:10.1016/j.renene.2015.12.036

study locations are historical extremes, the effect on system design was minimal, but pointed toward the benefits of PV investment when interest rates are high.

The system weight and its dimensions are key issues for the system mobility that is transported on reindeer sledges and can be decreased by half when optimizing loads with LEDs. The specific parameter of the system, i.e. the total system weight to the number of camp residents ratio varies somewhere between 5.8 to $10.6 \mathrm{~kg}$ per person for a low energy-intensive camp, and 11.0 to 20.3 for a high energy intensive one.

\section{Acknowledgement}

The authors would like to thank communities' representatives of the Ust-Nukzha village, Russia, including reindeer herders Vladimir A. Nickolaev and Galina S. Nickolaeva for their helpful explanations on reindeer husbandry details, and Nikolai I. Kascheev for the provision of financial data.

This publication is based on work conducted within the MSc programme SELECT, Environomical Pathways for Sustainable Energy Systems, which is a joint Master's programme offered by a consortium of universities with support from the European Union through EIT KIC InnoEnergy and Erasmus Mundus.

\section{References}

[1] Pearce JM. Photovoltaics — a path to sustainable futures. Futures 2002;34:663-74. doi:10.1016/S0016-3287(02)00008-3.

[2] Stutenbäumer U, Negash T, Abdi A. Performance of small-scale photovoltaic systems and their potential for rural electrification in Ethiopia. Renew Energy 1999;18:35-48. doi:10.1016/S0960-1481(98)00784-8.

[3] Adiyabat A, Kurokawa K. Performance analysis of portable photovoltaic power generation systems based on measured data in Mongolia. Photovolt Spec Conf 2002 Conf Rec Twenty-Ninth IEEE 2002:1664-7. doi:10.1109/PVSC.2002.1190937.

[4] Lau KY, Yousof MFM, Arshad SNM, Anwari M, Yatim AHM. Performance analysis of hybrid photovoltaic/diesel energy system under Malaysian conditions. Energy 2010;35:3245-55. doi:10.1016/j.energy.2010.04.008.

[5] Sen R, Bhattacharyya SC. Off-grid electricity generation with renewable energy technologies in India: An application of HOMER. Renew Energy 2014;62:388-98. doi:10.1016/j.renene.2013.07.028.

[6] Benghanem $M$, Hadj Arab A. Photovoltaic water pumping systems for Algeria. Desalination 2007;209:50-7. doi:10.1016/j.desal.2007.04.008.

[7] Higier A, Arbide A, Awaad A, Eiroa J, Miller J, Munroe N, et al. Design, development and deployment of a hybrid renewable energy powered mobile medical clinic with automated modular control system. Renew Energy 2013;50:847-57. doi:10.1016/j.renene.2012.07.036. 
Svetlana V. Obydenkova and Joshua M. Pearce. Technical viability of mobile solar photovoltaic systems for indigenous nomadic communities in northern latitudes. Renewable Energy, 89,253-267 (2016). DOI:10.1016/j.renene.2015.12.036

[8] Kalogirou SA. Photovoltaic Systems. In: Kalogirou SA. Sol. Energy Eng. Process. Syst., 2009, p. 469-519. doi:10.1016/b978-0-12-374501-9.00009-1.

[9] Get Your Power from the Sun. U.S. Department of Energy 2003, URL: http://www.nrel.gov/docs/fy04osti/35297.pdf (last accessed on July 28, 2015).

[10] Keating TJ, Walker A, Ardani K. Best Practices in PV System Operations and Maintenance SAPC Working Group 2015, URL: http://www.nrel.gov/docs/fy15osti/63235.pdf (last accessed on July 28, 2015).

[11] Jordan DC, Smith RM, Osterwald CR, Gelak E, Kurtz SR. Outdoor PV degradation comparison. Conf Rec IEEE Photovolt Spec Conf 2010:2694-7. doi:10.1109/PVSC.2010.5616925.

[12] Pearce JM. The case for open source appropriate technology. Environ Dev Sustain 2012;14:425-31. doi:10.1007/s10668-012-9337-9.

[13] Usher E, Jean G, Howell G. The use of photovoltaics in a northern climate. Sol Energy Mater Sol Cells 1994;34:73-81. doi:10.1016/0927-0248(94)90026-4.

[14] Tin T, Sovacool BK, Blake D, Magill P, El Naggar S, Lidstrom S, et al. Energy efficiency and renewable energy under extreme conditions: Case studies from Antarctica. Renew Energy 2010;35:1715-23. doi:10.1016/j.renene.2009.10.020.

[15] Olivier JR, Harms TM, Esterhuyse DJ. Technical and economic evaluation of the utilization of solar energy at South Africa's SANAE IV base in Antarctica. Renew Energy 2008;33:1073-84. doi:10.1016/j.renene.2007.05.044.

[16] Boccaletti C, Di Felice P, Santini E. Integration of renewable power systems in an Antarctic research station. Renew Energy 2014;62:582-91. doi:10.1016/j.renene.2013.08.021.

[17] Nieminen M, Heiskari U. Diets of freely grazing and captive reindeer during summer and winter. Rangifer 1989;9:17-34.

[18] Mathiesen S, Haga Ø. Diet composition, rumen papillation and maintenance of carcass mass in female Norwegian reindeer (Rangifer tarandus tarandus) in winter. Journal of Zoology 2000;251:129-38. doi:10.1111/j.1469-7998.2000.tb00598.x.

[19] McDonald NC, Pearce JM. Renewable Energy Policies and Programs in Nunavut: Perspectives from the Federal and Territorial Governments. Arctic 2012;65(4):465-75.

[20] McDonald NC, Pearce JM. Community Voices: Perspectives on Renewable Energy in Nunavut. Arctic 2013; 66(1):94-104.

[21] Clark RN. Operation and Maintenance: A Guide to Long-Term Operation and Maintenance Issues. In: Clark RN. Small Wind, Academic Press; 2014, p. 169-178. doi:10.1016/B978-0-12385999-0.00011-4.

[22] Forsyth T, Oteri F. Economic Considerations: Predicting the Economic Reality of an Installation. In: Clark RN. Small Wind, Academic Press; 2014, p. 159-168. doi:10.1016/B978-012-385999-0.00010-2.

[23] Battisti L. 14 - Optimising wind turbine design for operation in cold climates. Woodhead Publishing Limited; 2011. doi:10.1533/9780857090638.3.388.

[24] Barber S, Wang Y, Jafari S, Chokani N, Abhari RS. The Impact of Ice Formation on Wind Turbine Performance and Aerodynamics. J Sol Energy Eng 2011;133:011007. doi:10.1115/1.4003187. 
Svetlana V. Obydenkova and Joshua M. Pearce. Technical viability of mobile solar photovoltaic systems for indigenous nomadic communities in northern latitudes. Renewable Energy, 89,253-267 (2016). DOI:10.1016/j.renene.2015.12.036

[25] The Russian national census, 2010, URL: http://www.gks.ru/free doc/new site/perepis2010/croc/perepis itogi1612.htm (last accessed on July 15, 2015).

[26] The International Center for Reindeer Husbandry, URL: http://reindeerherding.org/ (last accessed on July 15, 2015).

[27] Filppa J. Reindeer husbandry in Finland. Rangifer 2005;25:59-62._Doi: http://dx.doi.org/10.7557/2.25.1.338.

[28] Statistics Canada, Government of Canada, URL: http://www.statcan.gc.ca/ (last accessed on July 15, 2015).

[29] Roturier S, Roué M. Of forest, snow and lichen: Sámi reindeer herders’ knowledge of winter pastures in northern Sweden. For Ecol Manage 2009;258:1960-7. doi:10.1016/j.foreco.2009.07.045.

[30] UN Educational, Scientific and Cultural Organization and UNESCO Institute of Information Technologies in Education Climate Change Adaptation: Traditional Knowledge of Indigenous Peoples Inhabiting the Arctic and Far North, URL: http://iite.unesco.org/courses/climate change/en/index.html (last accessed on July 15, 2015).

[31] Tyler NJC, Turi JM, Sundset M a., Strøm Bull K, Sara MN, Reinert E, et al. Saami reindeer pastoralism under climate change: Applying a generalized framework for vulnerability studies to a sub-arctic social-ecological system. Glob Environ Chang 2007;17:191-206. doi:10.1016/j.gloenvcha.2006.06.001.

[32] Manufacturer web-site” Rostehbyt”, “Washing machine, model BT-CM1RU”, URL: http://rostehbyt.ru/shop/printsessa/(last accessed on July 15, 2015).

[33] Lawrence Berkeley National Laboratory web-site. Standby power, URL: http://standby.lbl.gov/summary-table.html (last accessed on July 15, 2015).

[34] Manufacturer web-site "DDE United machines", "Gasoline-fired generator, model DDE GG950 DC”, URL: http://dde-um.com/catalog/generatory/generatory-benzinovye/generatorbenzinovyy-dde-gg-950-dc (last accessed on July 15, 2015).

[35] NASA Atmospheric Science Data Center, URL: https://eosweb.larc.nasa.gov/cgibin/sse/grid.cgi?email=skip@larc.nasa.gov (last accessed on July 15, 2015).

[36] Building climatology, SNiP 23-01-99*, 2003, URL: http://www.gosthelp.ru/text/SNiP230199Stroitelnayakli.html (last accessed on July 15, 2015).

[37] Betts AK, Ball JH. Albedo over the boreal forest. Journal of geophysical research 1997;102:28901-9. doi:10.1029/96JD03876.

[38] Andrews RW, Pearce JM. The effect of spectral albedo on amorphous silicon and crystalline silicon solar photovoltaic device performance. Sol Energy 2013;91:233-41. doi:10.1016/j.solener.2013.01.030.

[39] Russian Unified Interdepartmental Statistical Information System, URL: http://www.fedstat.ru/indicator/data.do?id=31448\&referrerType=1\&referrerId=1293294 (last accessed on July 15, 2015). 
Svetlana V. Obydenkova and Joshua M. Pearce. Technical viability of mobile solar photovoltaic systems for indigenous nomadic communities in northern latitudes. Renewable Energy, 89,253-267 (2016). DOI:10.1016/j.renene.2015.12.036

[40] Statistics Norway, Sales of petroleum products, URL: https://www.ssb.no/statistikkbanken/selectvarval/Define.asp?

subjectcode $=$ \&ProductId=\&MainTable=PetroleumSalg5\&nvl=\&PLanguage $=1 \&$ nyTmpVar $=$ true \&CMSSubjectArea=energi-og-

industri\&KortNavnWeb=petroleumsalg\&StatVariant=\&checked=true (last accessed on July 15, 2015).

[41] Financial Cbonds Information, URL: http://ru.cbonds.info (last accessed on July 15, 2015).

[42] Reuters Informational system

[43] Central Bank of Russia, URL: www.cbr.ru (last accessed on July 15, 2015).

[44] Bloomberg Informational system

[45] Product specification, "Solar module, MG Series", URL: http://www.hhigreen.com/solar/en/modules view?id=8 (last accessed on July 25, 2015).

[46] Product datasheet, “GEG Solar, GEG-180P”, URL: http://www.germaniaenergy.com/en/product/specification-poly-180-205-germania-energy.pdf (last accessed on July 20, 2015).

[47] Ikkala O, Nieminen A. Lead/acid batteries in arctic photovoltaic systems. J Power Sources 1990;31:321-7. doi:10.1016/0378-7753(90)80084-Q.

[48] Berndt D. VRLA batteries, advances and limitations. J Power Sources 2006;154:509-17. doi:10.1016/j.jpowsour.2005.10.083.

[49] BCI Battery service manual. 13th Edition, 2010. URL: https://batterycouncil.site-ym.com/store/ViewProduct.aspx?ID=1298166 (last accessed on July 20, 2015).

[50] Albright G, Edie J, Al-Hallaj S. A Comparison of Lead Acid to Lithium-ion in Stationary Storage Applications. AllCell Technol LLC 2012. URL: http://www.batterypoweronline.com/main/wp-content/uploads/2012/07/Lead-acid-white-paper.pdf (last accessed on July 27, 2015).

[51] Product datasheet, “Model T-105”, Trojan ${ }^{\circledR}$ battery company”, URL: http://www.trojanbattery.com/pdf/datasheets/T105 Trojan Data Sheets.pdf (last accessed on July 27, 2015).

[52] Product datasheet, "Model 6FM100E-X 12V 100Ah(10hr)”, Vision”, URL: http://www.vision-batt.com/site/product files/6FM100E-X.pdf (last accessed on July 27, 2015).

[53] Manufacturer web-site "Bright manufacturing”, URL http://brightmfg.com/220volt inverters.html (last accessed on July 27, 2015).

[54] "SolarServer, Global Solar Industry Website”, URL: http://www.solarserver.com/service/pvx-spot-market-price-index-solar-pv-modules.html (last accessed on July 20, 2015).

[55] Weinert JX, Burke AF, Wei X. Lead-acid and lithium-ion batteries for the Chinese electric bike market and implications on future technology advancement. J Power Sources 2007;172:938-45. doi:10.1016/j.jpowsour.2007.05.044. 
Svetlana V. Obydenkova and Joshua M. Pearce. Technical viability of mobile solar photovoltaic systems for indigenous nomadic communities in northern latitudes. Renewable Energy, 89,253-267 (2016). DOI:10.1016/j.renene.2015.12.036 